TOMASZ DYWAN

https://orcid.org/0000-0001-8348-823X

Instytut Historyczny Uniwersytetu Wrocławskiego

\title{
TRANSPORT PUBLICZNY WE LWOWIE \\ W LATACH 1879-1914. O PROBLEMATYCE WDRAŻANIA NOWOCZESNEJ INFRASTRUKTURY MIEJSKIEJ W GALICJI
}

Zarys treści: W artykule omówiono okoliczności wdrażania i użytkowania masowych środków transportu miejskiego we Lwowie. Problematyka została ukazana w szerszym kontekście polityki gospodarczej i społecznej samorządu miejskiego oraz warunków realizacji inwestycji w Galicji. W 1879 r. miasto zdecydowało się na zlecenie wykonania tramwaju konnego Triesteńskiemu Towarzystwu Tramwajowemu. Inwestor nie był jednak skłonny do rozbudowania wykonanych linii, dlatego samorzą miejski postanowił zlecić wykonanie tramwaju elektrycznego firmie Siemens \& Halske. Inwestycja okazała się na tyle udana, że miasto wykupiło tramwaj elektryczny i zdecydowało się go użytkować we własnym zarządzie. Pomimo konkurencji omnibusu i tramwaju konnego, tramwaj elektryczny - po rozbudowaniu linii w latach 1906-1910 stał się podstawowym środkiem transportu w mieście. Innowacyjność użytego napędu świadczy, że stolica Galicji nie odstawała w zakresie stosowania nowoczesnych rozwiązań infrastrukturalnych od innych wielkich miast monarchii.

The content outline: The text discusses the circumstances of development and use of urban public transport in Lviv. The issue is presented against a broader context of the social and economic policy of the municipal self-government and the conditions in which various infrastructural projects were implemented in Galicia. In 1879, the city issued a permit for the creation of a horse-drawn tram network to the Trieste Tramway Society (Società Triestina Tramway). The investor, however, was reluctant to further develop the original routes. Therefore, the self-government decided to commission the construction of electric tramway to the company Siemens \& Halske. The project proved so successful that the city eventually decided to buy the tramway and operate it on its own. Despite competition from omnibus and horse-drawn tram services, the electric tramway became the most popular means of public transport in Lviv after the expansion of the network in the years 1906-1910. The use of electricity as a source of power proved that Galicia did not lag behind other 
large cities of the monarchy in terms of innovation and adoption of cutting-edge infrastructural solutions.

Słowa kluczowe: Lwów, transport miejski, omnibus, tramwaj konny, tramwaj elektryczny, inwestycje komunalne, elektryfikacja, Triesteńskie Towarzystwo Tramwajowe (Società Triestina Tramway), Miejskie Koleje Elektryczne we Lwowie

Keywords: Lviv, public transport, omnibus, horse-drawn tram, electric tram, municipal investments, electrification, Trieste Tramway Society (Società Triestina Tramway), Municipal Electric Tramway in Lviv

Stulecie XIX charakteryzowały intensywne przemiany społeczne, polityczne i gospodarcze, których konsekwencją były m.in. uprzemysłowienie i urbanizacja. Coraz ludniejsze miasta generowały wiele problemów, które ich władze starały się rozwiązywać poprzez wdrażanie różnorakich rozwiązań technicznych, ułatwiających m.in. przemieszczanie się ${ }^{1}$. Historycy transportu zwracaja uwagę, że nowoczesny transport miejski powinien odznaczać się systemem stałych tras, rozkładem jazdy o określonej częstotliwości kursowania pojazdów i relatywnie tanią opłata za przejazd. Do spełnienia tych warunków konieczne było stworzenie odpowiedniego zaplecza, umożliwiającego sprawną realizację usług transportowych. Wówczas wykształciła się praktyka zawierania umów pomiędzy władzami miast a inwestorami, chcącymi udostępnić usługę masowego przewozu osób ${ }^{2}$. Początkowo przedsiębiorstwa transportowe wykorzystywały pojazdy zaprzęgane w konie: od $1823 \mathrm{r}$. omnibusy (Nantes), a od 1832 r. ciagnięte po szynach tramwaje konne (Nowy Jork) ${ }^{3}$. W latach siedemdziesiątych i osiemdziesiątych XIX w. siłę pociągową koni zaczęto zastępować mechanicznymi formami napędu (napęd parowy, sprężone powietrze, motory gazowe). Około 1900 r. najbardziej wydajnym rozwiązaniem okazał się napęd elektryczny ${ }^{4}$.

${ }^{1}$ J. Osterhammel, Historia XIX wieku. Przeobrażenie świata, tłum. z niem. I. Drozdowska-Broering, J. Kałążny, A. Peszke, K. Śliwińska, Poznań 2013, zwł. s. 325-330.

2 J.P. McKay, Tramways and Trolleys. The Rise of Urban Mass Transport in Europe, Princeton 1976, s. 8; J. Wesołowski, Transport miejski. Ewolucja i problemy wspótczesne, Łódź 2002 (Zeszyty Naukowe Politechniki Łódzkiej, 918; Rozprawy Naukowe, 319), s. 7, 27-28.

${ }^{3}$ J.P. McKay, dz. cyt., s. 13-16; J. Wesołowski, dz. cyt., s. 76.

${ }^{4}$ Rozwiązania mechanicznego napędu dla transportu miejskiego omówili: E. Hauswald, O systemach kolei miejskich, „Czasopismo Techniczne” (Lwów) 11, 1893, nr 17-18, s. 134-137, 141-143; A. Świętochowski, Drogi żelazne $w$ dużych miastach, „Przegląd Techniczny" 41, 1903, nr 41-52, s. 716. 
Celem niniejszego tekstu jest naświetlenie okoliczności wdrażania i eksploatacji nowoczesnych środków transportu w warunkach miasta rozwijającego się, ze względu na stołeczny status, jaki Lwów uzyskał po włączeniu do monarchii habsburskiej terytorium nazwanego Królestwem Galicji i Lodomerii. Usługi, handel, rzemiosło i w znacząco mniejszym stopniu przemysł zaczęły mieć coraz większy wpływ na wzrost liczby ludności miasta $\mathrm{w}$ końcu XIX i na początku XX w. ${ }^{5}$ Wówczas coraz większy wpływ na wprowadzanie nowoczesnych rozwiąań infrastrukturalnych miał miejski samorząd, ustanowiony na mocy specjalnej ustawy krajowej (Statut król. stoł. miasta Lwowa) z 1870 r. ${ }^{6}$ Korzystając m.in. z opublikowanej w 2020 r. monografii lwowskich tramwajów autorstwa Jana Szajnera i Marcina Rechłowicza ${ }^{7}$, postaram się wykazać, jak wskazane uwarunkowania wpłynęły na wdrażanie coraz bardziej zaawansowanych rozwiązań transportu miejskiego we Lwowie. Postaram się także ustalić, czy i w jakim stopniu rozwiązania te były typowe w porównaniu z innymi miastami środkowoeuropejskimi.

\section{Wdrożenie tramwaju konnego}

W latach pięćdziesiątych XIX w. inwestowanie kapitału w przedsiębiorstwa transportowe w miastach było dość ryzykownym przedsięwzięciem. Oferowane przez nie usługi regularnego przejazdu nie były wystarczająco tanie, aby stanowiły poważna konkurencję dla dorożek. Niżej sytuowani mieszkańcy miast nie mogli nazbyt często z nich korzystać. $\mathrm{Z}$ tych powodów dochodziło do częstych bankructw przedsiębiorstw omnibusów i tramwajów konnych. Pomimo niskiej liczby przejazdów spółki tramwajowe mogły przynosić dochody w dużych metropoliach, takich

\footnotetext{
${ }^{5}$ Spośród wielu opracowań por. m.in.: S. Hoszowski, Ekonomiczny rozwój Lwowa w latach 1772-1914, Lwów 1935; H. Madurowicz-Urbańska, Lwów - stolica Galicji. Stan badań nad demograficznym, gospodarczym, cywilizacyjnym rozwojem miasta doby autonomicznej, „Zeszyty Naukowe UJ. Prace Historyczne” 1195, 1996, nr 121 (Studia Austro-Polonica, 5), s. 167-172; K. Wnęk, L.A. Zyblikiewicz, E. Callahan, Ludność nowoczesnego Lwowa w latach 1857-1938, Kraków 2006, s. 31-32; J. Lewicki, Między tradycja a nowoczesnościq. Architektura Lwowa lat 1893-1918, Warszawa 2005, s. $36-45$.

${ }^{6}$ T.Ł. Sroka, Rada Miejska we Lwowie w okresie autonomii galicyjskiej 1870-1914. Studium o elicie wtadzy, Kraków 2012 (Uniwersytet Pedagogiczny im. Komisji Edukacji Narodowej w Krakowie. Prace Monograficzne, 621), s. 75-111, 141-144.

7 Zasadniczy zrab artykułu został opracowywany w latach 2016-2018, natomiast w 2020 r. do narracji włączono niektóre ustalenia z tej pracy bądź odniesiono się do nich w przypisach.
} 
jak np. Paryż, Berlin czy Wiedeń. Ten niekorzystny stan rzeczy uległ zmianie pod koniec lat sześćdziesiatych XIX w. Symptomem tego były sensacyjne zyski Berlińskiej Kolei Konnej (Berliner Pferde-Eisenbahn) z 1872 r., pozwalające na wypłatę akcjonariuszom 24\% dywidendy ${ }^{8}$. Spodziewając się zadowalających zysków, zrzeszenia różnych inwestorów przedłożyły wielu miejskim samorządom oferty wykonania i użytkowania tramwaju konnego. Wśród nich znalazły się dwa największe miasta galicyjskie - Lwów i Kraków9 .

W końcu czerwca 1868 r. ofertę uruchomienia tramwaju konnego we Lwowie złożyło władzom miasta zrzeszenie kilku galicyjskich inwestorów z hrabia Wilhelmem Siemieńskim-Lewickim (1827-1907) na czele ${ }^{10}$. W lipcu tegoż roku rada miejska powołała specjalną komisję do wyznaczenia przebiegu mających powstać na ulicach Lwowa linii tramwajowych $^{11}$. Podjęte $\mathrm{z}$ lwowskim samorządem negocjacje w sprawie zawarcia kontraktu - podobnie zresztą jak później w Krakowie - nie satysfakcjonowały inwestorów, którzy domagali się nazbyt długich okresów koncesji i nadmiernych zwolnień od podatków gminnych ${ }^{12}$. Dlatego inicjatywa ta nie doszła do skutku. Kolejna tego typu ofertę złożyli radzie miejskiej w końcu stycznia 1872 r. Aleksander Poradowski (1836-1890) wraz profesorem lwowskiej c.k. Szkoły Politechnicznej Józefem Jägermannem (1843-1927). Pierwszy z nich wskazywał radnym, że dzięki takiej inwestycji można by „ułatwić komunikację głównie tych osób, które przez szczupłość funduszy nie moga skracać czasu - prawdziwego pieniądza człowieka pracy - przeniesieniem się z jednego końca miasta na drugi, biorąc powozy jednokonki” ${ }^{13}$. Rozpatrujący tę ofertę urzędnicy III departamentu

8 J. Fischer-Dick, Die Strassenbahnen in den Städten, „Zeitschrift für gesamte Lokal und Straßenbahnwesen" 2, 1883, s. 40; T. Sielicki, Wrocławskie tramwaje konne, Wrocław 2017, s. 20-22.

9 J.P. McKay, dz. cyt., s. 16-17; T. Latos, Tramwaj konny w Krakowie (1882-1901), w: Spoteczeństwo, kultura, inteligencja. Studia historyczne ofiarowane Profesor Irenie Homoli-Skapskiej, red. E. Orman, G. Nieć, Kraków-Warszawa 2009 (Regiony, Historia, Kultura, 6), s. 271-272.

10 Державний архів Львівської області (dalej: DALO), Magistrat król. stoł. miasta Lwowa (dalej: f. 3), op. 1, sp. 2516, Imieniem konsorcjum do prezydium magistratu, Lwów, 24 VI 1868 r., k. 2. Okoliczności rozpatrywania ofert wykonania tramwaju konnego opisują J. Szajner, M. Rechłowicz, Tramwaje lwowskie 1880-1944, Łódź 2020, s. 23-24.

${ }^{11}$ DALO, f. 3, op. 1, sp. 2516 [Protokoły komisji powołanej przez radę miejska do zbadania przebiegu trasy projektowanych linii tramwajowych, Lwów, 1-28 VII 1868 r.], k. 4-22v.

12 Por. M. Moraczewski, Droga żelazna konna (tramway) w Krakowie, „Czasopismo Techniczne" (Kraków) 2, 1881, nr 3-6, s. 23.

${ }^{13}$ DALO, f. 3, op. 1, sp. 2516, A. Poradowski do prześwietnej rady miejskiej we Lwowie, Lwów, 24 I 1872 r., k. 23r-v. 
magistratu skonstatowali, że jest ona zbyt ogólnikowa. Zauważyli przy tym, że oferenci nie są w stanie sfinansować przedsięwzięcia. Podejrzewano, że starali się uzyskać od miasta koncesję, aby przekazać ja, oczywiście z zyskiem dla siebie, innej spółce tramwajowej ${ }^{14}$. Wobec takiego stanu rzeczy Poradowski sprowadził do Lwowa inż. Charlesa Llewellyna Lighta - pełnomocnika Towarzystwa Brytyjskich i Zagranicznych Tramwajów (The British \& Foreign Tramway Company). W jego imieniu złożono w magistracie projekt umowy, na mocy której chciano wykonać we Lwowie „kolej konną” i mieć prawo wyłącznego jej użytkowania przez 45 lat $^{15}$. W tymże roku konkurencyjną ofertę złożyli miastu Heinrich Hobohm i Rudolf Gablenz. Była ona również zaopatrzona w projekt umowy koncesyjnej ${ }^{16}$.

Latem 1872 r. z budżetu gminy miasta Lwowa sfinansowano podróż służbową komisarza drogowego Miejskiego Urzędu Budowniczego inż. Władysława Libla do Warszawy, Berlina, Hamburga, Lipska i Drezna. W trakcie podróży polecono mu zwiedzić również Wrocław, a następnie Pragę, Brno i Wiedeń. Urzędnik miał za zadanie rozeznać, w jaki sposób owe miasta wykonały i eksploatowały infrastrukturę techniczną ${ }^{17}$. Z uwagi na przedłożone miastu oferty szczególnie koncentrował się na kwestiach wykonania i użytkowania tramwajów konnych. W przedłożonym radnym sprawozdaniu zwracał uwagę, że tramwaj jest najbardziej opłacalny w dużych miastach z rozwiniętym przemysłem i handlem, gdzie mógł być wykorzystywany nie tylko do przewozu osób, ale także towarów. W przypadku miast rozwijajaccych się, a zatem także Lwowa, przy podejmowaniu inwestycji radził się skupić tylko na transporcie osobowym. W dalszej perspektywie „kolej konna” mogła przyczynić się do „ożywienia handlu, przemysłu i wszelkich innych interesów” i być najbardziej użyteczną dla „zarobkujących i średnich klas, dzięki prowadzeniu regularnych przewozów”. Ponieważ w 1872 r. użytkowano we Lwowie prawie 400 dorożek jednokonnych, których klienci przez wzgląd na atrakcyjna cenę przejazdu nie baczyli na niską jakość usług, Libl podkreślił regulacyjna funkcję transportu tramwajowego $\mathrm{w}$ miastach. Z jego dostępnością wiązano bowiem obniżenie ceny i poprawę

${ }^{14}$ DALO, f. 3, op. 1, sp. 2729, A. Poradowski i J. Jägermann do prześwietnej rady miejskiej król. stoł. miasta Lwowa, Lwów, 4 III 1872 r., k. 1r-v.

${ }^{15}$ DALO, f. 3, op. 1, sp. 2516, Koncesja na kolej żelazną konną w mieście Lwowie [Lwów, 1872 r.], k. 39-43v.

16 Tamże, Hoher Magistrat der königl. Hauptstadt Lemberg, oprac. H. Hobohm, R. Gablenz, Wien, 8 VIII 1872 r., k. 52-53v.

17 Tamże, Prześwietny wydział rady m[iejskiej], oprac. W. Libl, Drezno, 30 VII 1872 r., k. 49-50. 
jakości usług dorożkarskich, w tym eliminację z rynku najgorzej utrzymanych powozów. Następnie komisarz drogowy zalecał ograniczyć się we Lwowie do wykonania niewielkiej kolei konnej, umożliwiającej „połaczenie przedmieść i dworców kolei żelaznej z centrum miasta"18. Stąd wywodzi się koncepcja poprowadzenia linii tramwajowej od dworca Kolei Karola Ludwika w kierunku Śródmieścia, a stamtąd do dworca „kolei brodzkiej”, czyli późniejszej stacji Lwów Podzamcze.

Zarówno wybór któregoś z wymienionych powyżej oferentów, jak i realizację inwestycji w $1873 \mathrm{r}$. udaremnił kryzys gospodarczy wywołany spekulacyjna zwyżką cen akcji przedsiębiorstw przemysłowych na giełdzie wiedeńskiej ${ }^{19}$. Sam fakt złożenia tych ofert świadczy o próbie koncentracji kapitału nie tylko przez pozakrajowych inwestorów, ale także galicyjskich ziemian i majętnych lwowian. Podjęli oni próbę powołania spółki na wzór podobnych przedsięwzięć działających w wielkich miastach monarchii od 1865 r., kiedy to miasto Wiedeń udzieliło koncesji genewskiemu przedsiębiorcy Carlowi Schaeckowi-Jaquetowi. Gdy ów zbankrutował, Wiedeńska Spółka Tramwajowa (Wiener Tramway-Gesellschaft) zaczęła od 1868 r. rozbudowywać linie tramwaju konnego w stolicy Przedlitawii ${ }^{20}$. W ślad za tymi inicjatywami spółki tramwajowe w porozumieniu z miejskimi samorządami uzyskały koncesje rządowe na budowę „kolei konnych" w Budapeszcie (1866), Brnie (1869), Baden (1873), Pradze (1875), Trieście (1876), Grazu (1878), Linzu (1880) i Krakowie (1882) ${ }^{21}$.

Budowa infrastruktury ułatwiającej przemieszczanie się osób we wprawdzie peryferyjnej, ale rozwijającej się stolicy Galicji była kwestią czasu. Zgodnie z analizami sprawozdania Władysława Libla Miejski Urząd Budowniczy przedłożył szczegółowe warunki na budowę tramwaju konnego we Lwowie, które 23 lipca zostały zaakceptowane przez urzędników magistratu, a 9 X $1873 \mathrm{r}$. uchwalone przez radę miejska, jako obowiązujacce ${ }^{22}$. Na ich podstawie władze miasta chciały mieć wpływ na ustalanie cen przejazdu, jakich inwestor zamierzał zażądać

18 Tamże, Sprawozdanie o sposobach zakładania kolei konnych, ich korzyści i wadliwości po miastach, oprac. W. Libl [Lwów 1872 r.], k. 74v, 78-79v.

19 D.F. Good, The Economic Rise of the Habsburg Empire 1750-1914, Berkeley-Los Angeles-London 1984, s. 164-165, 204-205.

${ }_{20}$ P. Liez, Die Straßenbahnen, w: Wien am Anfang des XX. Jahrhunderts. Ein Führer in technischer und künstlerischer Richtung, t. 1: Charakteristik und Entwicklung der stadt. Ingenieurbauten, red. P. Kortz, Wien 1905, s. 123.

${ }^{21}$ K. Bachinger, Das Verkehrswesen, w: Die Wirtschaftliche Entwicklung, red. A. Brusatti, Wien 1973 (Die Habsburgermonarchie 1848-1918, t. 1, red. A. Wandruszka, P. Urbanitsch), s. 303-304.

${ }^{22}$ DALO, f. 3, op. 1, sp. 2516, Uchwała magistratu (rady miejskiej) z 9 (16) X 1873 r. w sprawie zaprowadzenia kolei konnej we Lwowie, k. 27-30. 
od potencjalnych klientów (§ 21). Koncesji zamierzano udzielić na 40 lat, w którym to czasie wybrane przedsiębiorstwo miało prawo wyłącznej budowy i eksploatacji w granicach miasta „kolei konnej” (§ 1). Inwestor zobowiązany był w pierwszej kolejności wykonać linię pomiędzy dworcem Kolei Karola Ludwika i stacja kolejową Lwów Podzamcze. Linia ta musiała być wybudowana przez Śródmieście (§ 7). Inwestor powinien zobowiązać się do wykonania dodatkowych linii na żądanie władz miasta w ciagu 2 lat. Gdyby tego nie uczynił, wówczas władze Lwowa mogły zaangażować innego przedsiębiorcę ${ }^{23}$.

Gdy zainwestowaniem kapitału w uruchomienie tramwaju konnego we Lwowie zainteresowało się Triesteńskie Towarzystwo Tramwajowe (Società Triestina Tramway, STT), musiało się skonfrontować z konkretnymi oczekiwaniami miasta. Ponieważ przedłożona oferta różniła się od warunków, o jakich była mowa powyżej, dlatego 16 i 17 XII 1878 r. przeprowadzono negocjacje z pełnomocnikiem STT - inż. Ludwikiem Filipem Schmidtem. W ich wyniku zdecydowano się wydłużyć okres koncesji o 10 lat, ale w zamian STT miało rozbudowywać linie tramwaju na warunkach jak najkorzystniejszych dla miasta, tzn. dostosowując się do najniższych cen oferentów takiej rozbudowy. Wówczas STT miała mieć pierwszeństwo wykonywania linii. Jeśliby tego nie uczyniła, miasto miało prawo zaangażować inne przedsiębiorstwo ${ }^{24}$. 2 II 1879 r. zawarto umowę, na mocy której STT zobowiązywało się ułożyć na własny koszt tory tramwajowe i zapewnić niezbędne do przewozu towarów i osób pojazdy (art. I). Przez wzgląd na poniesione koszty budowy i niepewne zyski, jakich spodziewano się w początkowym okresie funkcjonowania tramwaju, inwestor został zwolniony od podatków gminnych na 10 lat. Koncesja ograniczona została zapisami w art. II, gdzie włączono wynegocjowane ustalenia dotyczące prawa żądania budowy nowych linii przez miasto ${ }^{25}$. W ramach szczegółowych zapisów, która ze stron i w jakich

${ }^{23}$ DALO, f. 3, op. 1, sp. 2777, Uchwała magistratu w sprawie zaprowadzenia kolei konnej we Lwowie, Lwów, 23 VII 1873 r., k. 1-2v; M. Rechłowicz, J. Szajner, Poczatki tramwajów lwowskich (1880-1896), w: Archeologia przemysłowa w Polsce, t. 4, red. S. Januszewski, Wrocław 2013, s. 88-89.

${ }^{24}$ DALO, f. 3, op. 1, sp. 2777, Protokół posiedzenia z 8 I 1879 r. komisji specjalnej ustanowionej [...] dla rokowań z towarzystwem STT celem nadania temuż koncesji na budowę i użytkowanie kolei konnej we Lwowie, k. 36v; DALO, f. 3, op. 1, sp. 3008, Protokół rokowań przeprowadzonych 16 i 17 I 1878 r. przez komisję specjalną ustanowioną uchwałą rady miejskiej [...] z P. Ludwikiem Filipem Schmidt, zastępcą towarzystwa STT celem nadania rzeczonemu towarzystwu koncesji na budowę i użytkowanie kolei konnej we Lwowie, k. 2.

${ }^{25}$ DALO, f. 3, op. 1, sp. 3043, Umowa, która między gminą kr. st. miasta Lwowa z jednej a towarzystwem akcyjnym STT [...], Lwów, 2 II 1879 r., k. 11r-v (s. 1-2). 
okolicznościach ma ponosić koszty utrzymania linii tramwajowych, ustalono ceny biletów (art. XVIII). Wynosiły one za przejazd jedna sekcją 5 (I klasa) i 4 (II klasa) centy. Ponadto wyznaczono trasę linii tramwajowych: od dworca Kolei Karola Ludwika przez ulice Gródecka, Kazimierzowska (ob. Gródecka), pl. Gołuchowskich (w tym miejscu wystawiono w latach 1898-1900 gmach Teatru Miejskiego, ob. opery), pl. Krakowski, ul. Żółkiewską do rogatki żółkiewskiej. Następnie od pl. Gołuchowskich, przez ul. Karola Ludwika (ob. Prospekt Swobody), place Mariacki (ob. pl. A. Mickiewicza), Halicki, Bernardyński (ob. pl. Soborna) do krańcówki na pl. Cłowym (zob. mapa 1$)^{26}$.

W końcu maja 1879 r. STT przedłożyło do akceptacji lwowskiego magistratu szczegółowe projekty na wykonanie torów z typowymi dla tramwajów konnych tanimi szynami drewniano-stalowymi o rozstawie $1435 \mathrm{~mm}^{27}$ oraz na budowę kompleksu zajezdni, stajni i budynku administracyjnego przy ul. gen. J. Bema (ob. Jarosława Mądrego 11)28. Członkom powołanej przez radnych komisji tramwajowej zależało na tym, aby wagony tramwajowe mogły swobodnie zawracać przed gmachem dworca kolejowego, a wykonywane linie miały dwa tory, umożliwiające sprawny kurs wagonów w przeciwnych kierunkach ${ }^{29}$. Ostatni wymóg należy uznać za szczególny obowiązek nałożony na inwestora, ponieważ

Okoliczności zawarcia umowy opisują: Rada miasta Lwowa (posiedzenie z dnia 23 stycznia), „Gazeta Lwowska”, 24 I 1879, s. 4; Kronika miejscowa i zamiejscowa. Dnia 4 lutego, „Gazeta Narodowa”, 5 II 1879, s. 2; K. Ostaszewski-Barański, Poglad na dziatalność Reprezentacji król. stołecznego miasta Lwowa w okresie 1871-1895, w: Miasto Lwów w okresie samorzqdu 1870-1895, Lwów 1896, s. 150-151, 203-204.

${ }^{26}$ DALO, f. 3, op. 1, sp. 3043, Umowa, która między gminą kr. st. miasta Lwowa z jednej a towarzystwem akcyjnym STT [...], Lwów, 2 II 1879 r., k. 13v (s. 4). Plan położenia torów tramwajowych w jezdniach ulic załączono do sprawozdania opisującego wykonywane linie tramwajowe, zob. DALO, f. 3, op. 1, sp. 3108, STT do magistratu miasta Lwowa [Lwów, VI/VII 1880 r.], k. 6-22.

27 Szczegółowe projekty torowisk tramwajowych przechowuje DALO, Zarząd król. stoł. miasta Lwowa (dalej: f. 2), op. 1, sp. 1809, Oberbau-Normalien, oprac. E. Peschl [IV 1879 r.], k. 30; DALO, f. 2, op. 1, sp. 1811, Oberbau-Normalien, oprac. E. Peschl [IV 1879 r.], k. 7. O konstrukcji torów tramwajowych z lat siedemdziesiątych XIX w. por. T. Sielicki, dz. cyt., s. 29-30, 254-255 (il. 16, 230).

${ }^{28}$ Projekty architektoniczne tego założenia przechowuje DALO, f. 2, op. 1, sp. 1811, Dokumentacja i projekty zabudowań parceli przy ul. Gródeckiej 6, k. 1-2, 18-19. Szczegółowo dokumentację tę analizują: М.Я. Шингельский, Передулови i iсторія створення кінного тралваю у Львові, „Дослідження з історії техніки” 6, 2005, s. 98-99; T. Dywan, Od „szkoty berlińskiej” do secesji. Przyczynek do architektury miejskich zakładów przemystowych Lwowa w latach 1858-1914, „Modus. Prace z Historii Sztuki” 19, 2019, s. 174-177.

${ }^{29}$ DALO, f. 3, op. 1, sp. 3106, Uchwała komisji tramwajowej na posiedzeniu 23 III 1880 r., k. $17 \mathrm{v}-18$. 
w przypadku budowy pierwszych linii tramwajowych w środkowoeuropejskich miastach wykonywano je na ogół jako jednotorowe. Na wyznaczonych odcinkach takich linii urządzano dwutorowe „mijanki”, pozwalające na wyminięcie się wagonów jadących w przeciwnych kierunkach ${ }^{30}$. Takie rozwiązanie pozwalało oszczędzić kapitał, lecz było przyczyna utrudnień w kursowaniu wagonów. Władze samorządowe Lwowa postanowiły wyeliminować tę wadę funkcjonowania ruchu tramwajowego poprzez skłonienie inwestora do wykonania linii dwutorowych.

$5 \mathrm{~V} 1880$ r. rozpoczęto regularny ruch wagonów od pl. Cłowego do tymczasowej krańcówki, wykonanej na ul. Gródeckiej przed kościołem św. Anny ${ }^{31}$. Pozwolenie na prowizoryczne użytkowanie linii na odcinku od kościoła św. Anny do dworca Kolei Karola Ludwika uzyskano 1 VII $1880 \mathrm{r}^{32}$ Wykonanie linii w kierunku rogatki żółkiewskiej wymagało zgody zarządu Kolei Karola Ludwika na kolizyjne skrzyżowanie torów tramwajowych z kolejowymi. Dlatego uruchomienie tej linii miało miejsce 1 IX $1880 \mathrm{r} \cdot{ }^{33}$ Po wykonanych torach tramwajowych co 10 (latem) lub co 12 minut (zima) kursowały wagony, które zatrzymywały się na dziesięciu przystankach I linii (dworzec Kolei Karola Ludwika-pl. Cłowy) i sześciu przystankach II linii (pl. Gołuchowskich-rogatka żółkiewska) ${ }^{34}$.

Podczas komisyjnego odbioru wykonanych linii miejscy urzędnicy zauważyli, że STT ułożyło tory tramwajowe nieco inaczej, niż wynikało to z ustalonych w wyniku pertraktacji szczegółowych planów. Skutkiem tego lwowski magistrat udzielił warunkowego zezwolenia na użytkowanie linii, zgłaszając jednocześnie zastrzeżenia co do jakości wykonania torów ${ }^{35}$.

30 J. Wesołowski, dz. cyt., s. 88. Por. o budowie linii tramwaju konnego w Warszawie, Wrocławiu i Krakowie: T. Latos, dz. cyt., s. 273-276; D. Walczak, Warszawskie tramwaje konne 1866-1908. Wydanie jubileuszowe z okazji 150 rocznicy uruchomienia pierwszego tramwaju $w$ Warszawie 11 grudnia 1866 roku, Rybnik 2016, s. 27-29; T. Sielicki, dz. cyt., s. 258-259.

31 Центральний державний історичний архів України, Львів (dalej: CDIAUL), Namiestnictwo galicyjskie (dalej: f. 146), op. 68, sp. 2611, Sprawozdanie magistratu miasta Lwowa, Lwów, 9 V 1880 r., k. 36-39v; DALO, f. 3, op. 1, sp. 3106, STT do magistratu miasta Lwowa, Lwów, 25 VI 1880 r., k. 66; Tramwaj, „Gazeta Lwowska”, 5 V 1880, s. 3.

${ }^{32}$ CDIAUL, f. 146, op. 68, sp. 2611, Sprawozdanie magistratu miasta Lwowa, Lwów, 17 VIII 1880 r., k. 67r-v.

${ }^{33}$ DALO, f. 3, op. 1, sp. 3106, Oświadczenie, Lwów, 27 VII 1880 r., k. 115r-v; Tramway lwowski, „Dźwignia. Organ Towarzystwa Ukończonych Techników we Lwowie” 4, 1880, nr 5, s. 39; Tramwaj lwowski, „Gazeta Lwowska”, 10 IX 1880, s. 3.

${ }^{34}$ Rada miasta Lwowa, „Kurier Lwowski”, 23 X 1885, s. 5; Przewodnik po Lwowie wydany przy wspótudziale Wydziału Gospodarczego V. Zjazdu Lekarzy i Przyrodników Polskich, Lwów 1888, s. 18.

${ }_{35}$ DALO, f. 3, op. 1, sp. 3106, Zmiany w założeniu torów kolei konnej w porównaniu do zatwierdzonych planów, Lwów, 24 XI 1883 r., k. 10-11v; tamże, Memoriał STT 


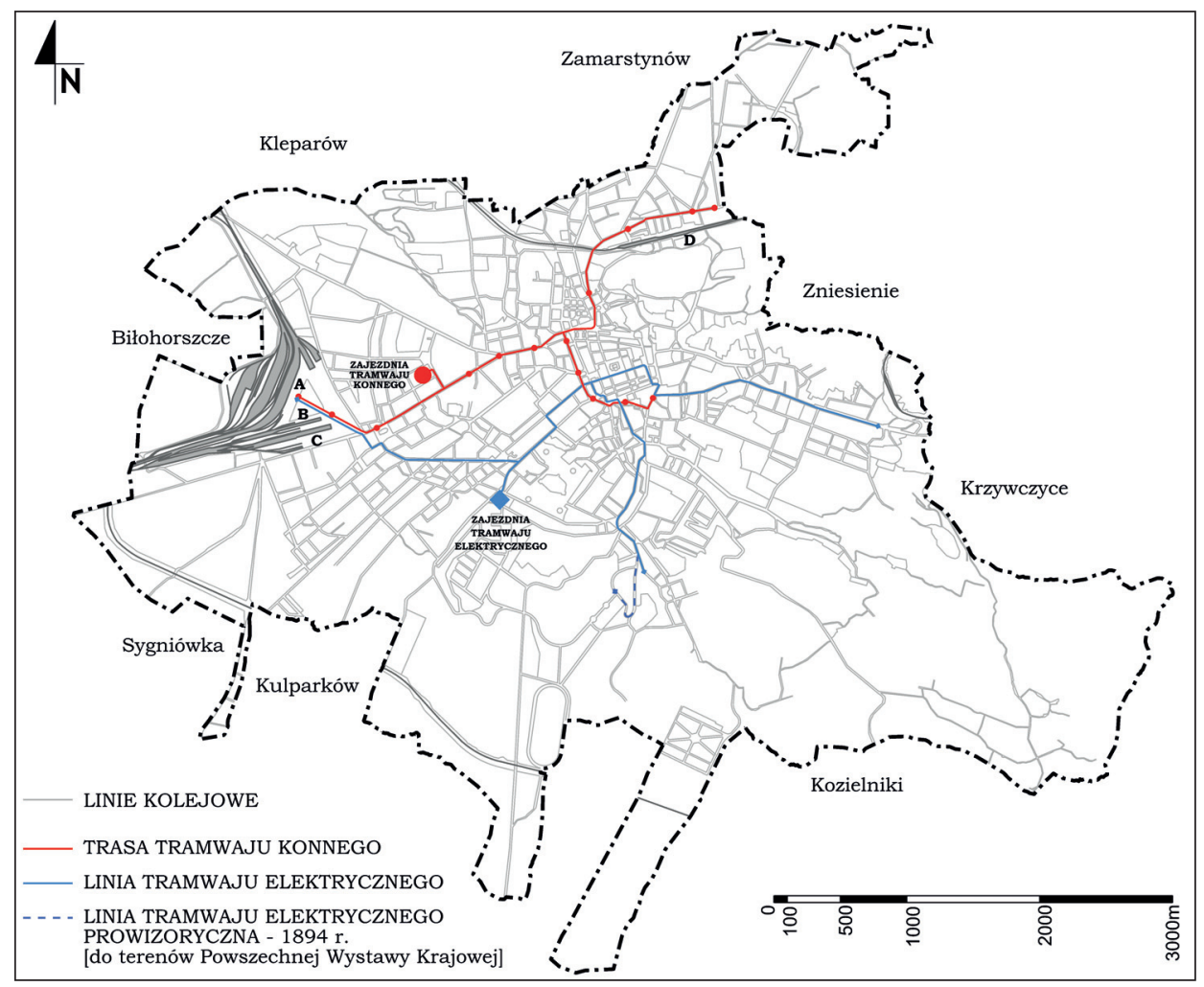

Mapa 1. Trasy linii tramwaju konnego i elektrycznego we Lwowie w końcu 1894 r.; rys. D. Grygiel.

Legenda: A - dworzec c.k. Kolei Państwowych, B - Dworzec Przemyski, C - dworzec Kolei Czerniowieckiej, D - stacja kolejowa Lwów Podzamcze.

Kiedy 2 lata późnej zamierzano wybrukować ul. Gródecka, wówczas wezwano STT do przełożenia torów zgodnie z zatwierdzonymi planami, tak aby przejazd wagonów odbywał się środkiem ulicy, a po bokach jezdni pozostawało wolne miejsce dla ruchu kołowego ${ }^{36}$. Wbrew podjętym ustaleniom linia tramwaju na ul. Żółkiewskiej została wykonana w dwóch odcinkach jako jednotorowa i nie miała dodatkowego objazdu, który stanowiłby alternatywne skrzyżowanie z torami kolejowymi. Stąd urzędnicy magistratu domagali się położenia drugiego toru i zagrozili, że miasto nie udzieli zgody na użytkowanie tej linii tramwajowej. Położenie brakującego toru na końcu linii miało miejsce dopiero 2 lata

w sprawie budowy torów, Lwów, 28 V 1880 r., k. 41-44; DALO, f. 3, op. 1, sp. 3108, STT do magistratu miasta Lwowa, Lwów [VI/VII 1880 r.], k. 1-4v.

${ }^{36}$ DALO, f. 3, op. 1, sp. 3221, Odpis z protokołu posiedzenia sekcji III rady miejskiej 14 VIII 1882 r., k. 37. 
później ${ }^{37}$. Spory w kwestii uznania wykonanych torów zgodnie z zatwierdzonymi wcześniej planami pozostawały nierozwiązane do $1893 \mathrm{r}$., a ruch tramwajowy odbywał się na podstawie „prowizorycznego zezwolenia”. Był to jeden $\mathrm{z}$ argumentów, który władze miasta wykorzystywały w sporach z STT.

\section{Relacje miasta \\ z Triesteńskim Towarzystwem Tramwajowym}

W pierwszych 10 latach użytkowania tramwaju STT nie było zainteresowane przedłużeniem wykonanych linii, gdyż lwowska inwestycja nie przynosiła zbyt wysokich zysków. Dlatego wobec przedłożonych przez urzędników magistratu w 1882 i 1886 r. propozycji położenia torów w ul. Łyczakowskiej STT oświadczyło, że taka linia „wcale nie przedstawia widoków pomyślnego oprocentowania" ${ }^{38}$. Podobnie było w przypadku kolejnych inicjatyw - przedłużenia torów na Łyczaków oraz do Parku Kilińskiego (ob. Park Stryjski), jakie STT złożył lwowski magistrat w 1890 r. Dyrekcja triesteńskiej spółki odmówiła z uwagi, że linia poprowadzona w kierunku parku byłaby intensywnie użytkowana jedynie $\mathrm{w}$ dni świąteczne latem ${ }^{39}$. Kwestia większej dostępności transportu publicznego we Lwowie okazała się paląca, kiedy władze krajowe zdecydowały się na zorganizowanie w $1894 \mathrm{r}$. wystawy majacej na celu zaprezentowanie osiagnięć gospodarczych i kulturalnych społeczeństwa zamieszkującego Galicję. Ta doniosła impreza miała w zamierzeniu organizatorów niwelować stereotyp Galicji jako biednego i zacofanego gospodarczo kraju monarchii oraz wzbudzić w zwiedzających „wiarę we własne siły” ${ }^{40}$. Zrozumiałe jest zatem, że władze

${ }^{37}$ CDIAUL, f. 146 , op. 68 , sp. 2611, Plan sytuacyjny podwójnego toru tramwajowego między pl. Krakowskim a Starym Rynkiem, Lwów, 2 V 1891 r., k. 256; M. Rechłowicz, J. Szajner, dz. cyt., s. 92-93.

${ }^{38}$ DALO, f. 3, op. 1, sp. 3221, STT do magistratu miasta Lwowa, Lwów, 14 I 1882 r., k. 74r-v. Sytuację tę opisuje także: Tramwaj na Eyczakowie, „Kurier Lwowski”, 27 III 1886, s. 2.

${ }^{39}$ Tramwaj Lwowski, „Kurier Lwowski”, 7 VI 1891, s. 1-2.

40 S. Tarnowski, Wstep, w: Powszechna Wystawa Krajowa we Lwowie w 1894 r., Kraków 1896, s. III-XII. Takie aspekty przesłania wystawy podkreślaja: J. Purchla, Kraków i Lwów: zmienność relacji w XIX i XX wieku, w: Kraków i Lwów w cywilizacji europejskiej. Materiaty międzynarodowej konferencji zorganizowanej $w$ dniach 15-16 listopada 2002, red. J. Purchla, Kraków 2003, s. 86-87; Ł.T. Sroka, dz. cyt., s. 139-141; W. Puchta, Powszechna Wystawa Krajowa we Lwowie w 1894 roku, Wrocław 2016 (Kulturoznawstwo Historyczne, 1), s. 51-58. 
miasta chciały zapewnić zwiedzającym transport z dworca kolejowego na tereny wystawowe przy Parku Kilińskiego.

Zgodnie z zapisami umowy z 1879 r. lwowski magistrat wystosował do STT żądanie wykonania linii tramwajowej do przyszłych terenów wystawowych. Negocjacje prowadzone ze spółką za pośrednictwem dyrekcji Lwowskiej Kolei Konnej przeciagały się, co szczególnie irytowało radnych i urzędników miejskich. STT nie było zainteresowane budowa linii, która byłaby intensywnie wykorzystywana podczas wystawy, a później mogła się okazać „deficytowa”. Do otwarcia wystawy pozostawało coraz mniej czasu, dlatego zniecierpliwieni radni i urzędnicy, zainspirowani odczytami i wykładami lwowskich inżynierów na temat elektryczności, podjęli zamysł wykonania we Lwowie tramwaju o napędzie elektrycznym. STT starało się wszelkimi sposobami uniemożliwić realizację tego pomysłu, twierdząc, że monopol spółki obejmuje budowę i użytkowanie jakiejkolwiek kolei lokalnej - a do takiej zaliczano linie tramwajowe - w granicach miasta. Radni zdecydowali się nie pertraktować z STT, gdyż w zawartej umowie koncesyjnej była mowa o budowie i użytkowaniu „kolei konnej”. Zdaniem urzędników miasto miało prawo samo wykonać bądź zlecić innemu inwestorowi wykonanie linii tramwaju elektrycznego, korzystając z ograniczeń, jakie nałożono na monopol uzyskany przez $\mathrm{STT}^{41}$. Dlatego w lwowskiej prasie wyjaśniano opinii publicznej, że ,żadnego sądu polubownego nie potrzeba, bo sprawa jest jasna i czysta" 42 .

Kiedy gmina miasta Lwowa pozwała jednak STT przed sąd polubowny, korzystny wyrok dla miasta na podstawie orzeczenia z $17 \mathrm{~V}$ 1893 r. nie był dla nikogo zaskoczeniem ${ }^{43}$. Aby zneutralizować konkurencję tramwaju elektrycznego, dyrekcja STT postanowiła wykorzystać fakt, że należace do niej tory tramwajowe zostały ułożone w głównych ulicach miasta. Nie chciano się zgodzić na ich krzyżowanie z torami tramwaju elektrycznego. Stąd 4 XI 1893 r. sprzeciwiono się projektowanemu kolizyjnemu skrzyżowaniu torów obydwu przedsiębiorstw na pl. Halickim. Spór udało się rozwiązać polubownie. W zamian za uzyskanie zgody na skrzyżowanie torów tramwajowych miasto odstapiło od wielu żądań wobec STT ${ }^{44}$. Ponieważ linia tramwaju elektrycznego,

${ }^{41}$ Rada miasta Lwowa, „Gazeta Lwowska”, 31 III 1893, s. 4.

${ }_{42}$ Tramwaj konny przeciw elektrycznemu, „Kurier Lwowski”, 16 III 1893, s. 4-5; Rada m. Lwowa, „Kurier Lwowski”, 24 III 1893, s. 5.

${ }^{43}$ DALO, f. 3, op. 1, sp. 4008, Odpis wierzytelny wyroku sądu polubownego w sporze gminy miasta Lwowa z towarzystwem akcyjnym STT, k. 66r-v.

${ }^{44}$ Miasto uznawało wykonane tory tramwajowe za wadliwe, przez co nie wypłacono STT zdeponowanej kaucji w kwocie 25 tys. guldenów. Ponadto domagano się od inwe- 
będąca do końca lipca 1896 r. własnością spółki Siemens \& Halske, okazała się zyskowna, dyrekcja STT zaczęła starania o zgodę władz Lwowa na zelektryfikowanie linii tramwaju konnego ${ }^{45}$. Gdyby udało się tego dokonać, spółka uzyskałaby rozszerzenie koncesji z 23 VI 1879 r., na co miasto nie chciało jednak przystać.

Konflikt STT z gmina miasta Lwowa osiagną apogeum na przełomie wieków, co wynikało z istotnej zmiany polityki inwestycyjnej miasta. Elity zarządzające galicyjską stolicą uznały, że podobnie jak w wielkich miastach monarchii, również we Lwowie to miejski samorząd powinien finansować i realizować inwestycje infrastrukturalne. Na tym tle, co było typowe w ostatniej ćwierci XIX w., dochodziło do konfliktów pomiędzy władzami municypalnymi a spółkami dążącymi do utrzymania monopoli na produkcję i sprzedaż gazu oraz użytkowanie tramwajów konnych ${ }^{46}$. Władze samorządowe Lwowa zamierzały pozyskać kapitał 20 mln koron poprzez emisję obligacji komunalnych, przeprowadzaną od 1895 r. przez Bank Krajowy Królestwa Galicji i Lodomerii ${ }^{47}$. Z tych środków chciało odkupić od spółki Siemens \& Halske tramwaj elektryczny i w dalszej perspektywie przystapić do rozbudowy miejskich linii tramwajowych.

Broniąc swoich interesów, 5 XII 1899 r. STT złożyło miastu ofertę zawarcia spółki. Spółka chciała objąć zarząd już istniejących i mających powstać linii tramwajowych na 50 lat z prawem wykupu udziałów przez miasto po upływie 20 lat. Miasto miało budować tory na własny koszt i być ich właścicielem, STT zaś miało zapewnić środki ruchu - tabor, warsztaty, zajezdnie i elektrownie ${ }^{48}$. Jednak spory miasta z triesteńską spółka, jakie miały miejsce przed otwarciem Powszechnej Wystawy Krajowej sprawiły, że postrzegano ją jako „hamulec rozwoju miasta”.

stora opłat naliczanych za usuwanie śniegu z ulic, w których ułożono tory tramwajowe, w kwocie 3063 guldenów; zob. DALO, f. 3, op. 1, sp. 4080, Protokół spisany z powodu odbytych 18 i 20 XII 1893 r. rokowań komisji elektrycznej z zastępca towarzystwa STT dyrektorem Schmidtem, k. 11-13v; DALO, f. 3, op. 1, sp. 3043, Umowa dodatkowa, która między gminą st. król. miasta Lwowa z jednej a towarzystwem STT, Lwów, 5 IV 1894 r., k. 21.

${ }^{45}$ DALO, f. 3, op. 1, sp. 4080, STT an den löblichen Stadt Repräsentantz, Triest, 15 III 1896 r., k. 23r-v; Zmiana lwowskiego tramwaju konnego na elektryczny, „Słowo Polskie”, 28 III 1896, s. 4.

${ }^{46}$ G. Melinz, S. Zimmermann, Die aktive Stadt. Kommunale Politik zur Gestaltung städtischer Lebensbedingungen in Budapest, Prag und Wien (1867-1914), w: Wien Budapest - Prag. Blütezeit der Habsburgermetropolen. Urbanisierung, Kommunalpolitik, gesellschaftliche Konflikte (1867-1918), red. G. Melinz, S. Zimmermann, Wien 1996, s. $140-176$.

${ }^{47}$ K. Ostaszewski-Barański, dz. cyt., s. 120-122; T.Ł. Sroka, dz. cyt., s. 132-133, 332-333.

${ }^{48}$ DALO, f. 3, op. 1, sp. 4008, Ostateczny wynik pertraktacji z STT, k. 67-68v. 
Podobnie zresztąjak posiadajace monopol na produkcję i sprzedaż gazu we Lwowie Niemieckie Kontynentalne Towarzystwo Gazowe z Dessau ${ }^{49}$. Dlatego uchwała z 18 XII 1902 r. rada miejska uznała przedłożoną jej propozycję za niekorzystna ${ }^{50}$. Zdecydowano się nie kontynuować pertraktacji i wykonać nową linię tramwaju elektrycznego od Wałów Hetmańskich (ob. Prospekt Swobody) przez ulice: Słoneczna (ob. P. Kulisza), Zamarstynowską Panieńską (ob. Zawodska) i św. Marcina (ob. Żółkiewska) do nowej rzeźni miejskiej na Gabrielówce (ob. ul. Przemysłowa) ${ }^{51}$. W reakcji na taka politykę miasta dyrekcja STT oświadczyła, że nie wyrazi zgody na krzyżowanie torów tramwaju konnego z elektrycznym. Sytuacja była patowa, gdyż uniemożliwiała rozbudowę linii tramwaju elektrycznego ${ }^{52}$. Jeśli gmina miasta Lwowa nie chciała wchodzić w jakąkolwiek spółkę z STT miała tylko jedno wyjście - wykup koncesji i majątku należącego do triesteńskiego towarzystwa we Lwowie.

Powołane przez radę miejską komisje budżetowa i elektryczna zajęły się zaopiniowaniem kwestii wykupu przez miasto przedsiębiorstwa tramwaju konnego. Po skrupulatnych wyliczeniach przychodów przedsiębiorstwa zalecono „uwolnić miasto od uciążliwego i krępującego je stosunku z tramwajem konnym”. Jego wykupienie uznano za konieczny „warunek racjonalnej organizacji sieci kolei elektrycznej”ㄹ. Wnioski te zdawały się potwierdzać opinie innych ekspertów, w tym pierwszego dyrektora Lwowskiej Kolei Elektrycznej inż. Aleksa Kerna i jego następcy, nominowanego przez władze miasta inż. Józefa Tomickiego (1863-1925) ${ }^{54}$. Tomicki zwracał uwagę, że kierowane przez niego przedsiębiorstwo przysparza miastu dochodów, które wystarczają na spłatę zaciagniętych pożyczek,

49 T. Dywan, Przemyst gazowniczy we Lwowie w latach 1858-1914. Przyczynek do dziejów industrializacji miasta, RDSG, t. 79, 2018, s. 102.

${ }^{50}$ DALO, f. 3, op. 1, sp. 4432, Odpis z posiedzenia komisji elektrycznej z $10 \mathrm{X}$ 1902 r., k. 24-25v.

${ }^{51}$ Miasto uzyskało wówczas koncesję rządową na budowę trzech linii: do nowej rzeźni miejskiej, do Pohulanki i do rogatki janowskiej, pod warunkiem porozumienia z STT w kwestii krzyżowania torów tramwajowych obydwu przedsiębiorstw; zob. AGAD, C.k. Ministerstwo Kolei Żelaznych (dalej: zesp. 310), sygn. 362a, Magistrat der königl. Hauptstadt Lemberg an das k.k. Eisenbahnministerium, Lwów, 12 VI 1902 r, s. 846-847; Rozszerzenie sieci kolei elektrycznej miejskiej, „Słowo Polskie”, 12 VIII 1902, s. 1; Miejska kolej elektryczna, „Lwowianin”, 10, 1902, nr 12, s. 94.

${ }^{52}$ DALO, f. 3, op. 1, sp. 4774, Sprawozdanie i wnioski komisji elektrycznej w sprawie wykupu kolei konnej, Lwów, 17 II 1906 r., k. 47r-v (s. 3-4).

${ }^{53}$ DALO, f. 3, op. 1, sp. 4008, Do rady miejskiej, oprac. G. Małachowski, N. Löwenstein, Lwów, 18 VII 1903 r., k. 71v (s. 6).

${ }_{54}$ P. Rataj, Józef Tomicki (1863-1925) - pionier elektroenergetyki lwowskiej, „Przegląd Zachodniopomorski” 31 (80), 2016, nr 3, s. 19. 
a nawet powstaje nadwyżka, którą można by zainwestować w rozszerzenie sieci tramwajowej. Jego zdaniem nie było żadnych powodów, które by „zmuszały gminę [miasta Lwowa - T.D.] do przyjmowania propozycji niegodnych i na zysk osób trzecich obliczonych, a przede wszystkim do oddawania z rak tak żywotnej sprawy miejskiej, jak sprawy komunikacji”. Dlatego zalecał finansowanie inwestycji z własnych środków i utrzymywanie jej we własnym zarządzie, „bez uciekania się do pomocy spekulantów" ${ }^{55}$. Na kolejnych posiedzeniach komisji elektrycznej uznawano propozycję STT za „niedogodna a nawet szkodliwa”. Sprzeciw STT na skrzyżowanie torów tramwaju konnego z elektrycznym znów chciano skierować do sądu polubownego.

Triesteńska spółka prowadząca na terenie miasta własne przedsiębiorstwo tramwajowe okazywała się coraz bardziej niewygodna. Radni oswoili się z myślą o konieczności jej wykupienia. Jedynym problemem pozostawała suma, jaką należało wypłacić STT. Zapisy umowy z 1879 r. nie przewidywały, że po wygaśnięciu koncesji przedsiębiorstwo tramwajowe miało przejść na własność miasta, tak jak to się stało w przypadku lwowskiej gazowni56 ${ }^{56}$ Było to typowe dla umów koncesyjnych regulujących użytkowanie tramwajów konnych. Po wygaśnięciu koncesji municypia miały prawo przejać jedynie ułożone na ulicach tory ${ }^{57}$. Stąd wykupienie tramwaju konnego przed wygaśnięciem koncesji musiało uwzględniać zarówno zyski czerpane przez STT, jak i posiadane nieruchomości, żywy inwentarz i pojazdy ${ }^{58}$. W kwietniu 1903 r. sprawozdawca komisji budżetowej Natan Löwenstein (1859-1929) obliczył koszty wykupu tramwaju konnego na sumę 900 tys. koron ${ }^{59}$. Kwota ta wydawała się lwowskim radnym zbyt duża. Dlatego negocjacje przeciagały się przez kolejne 2 lata, co uniemożliwiało rozbudowę linii tramwaju elektrycznego ${ }^{60}$. Błędne koło zostało przerwane, kiedy zdecydowano się

${ }_{55}$ DALO, f. 3, op. 1, sp. 4432, Opinia, oprac. J. Tomicki, Lwów, 19 X 1901 r., k. 7v.

${ }^{56} \mathrm{Na}$ mocy umowy z $1856 \mathrm{r}$. zakład gazowy i sieć gazociagów zostały przejęte 1 IX 1898 r. na własność gminy miasta Lwowa po wygaśnięciu 40-letniej koncesji na produkcję i sprzedaż gazu; zob. T. Dywan, Przemyst gazowniczy we Lwowie..., s. 98-102.

${ }^{57}$ DALO, f. 3, op. 1, sp. 2516, Projekt do postanowień dotyczących założenia i urządzenia żelaznej kolei konnej w obrębie król. stoł. miasta Lwowa, oprac. W. Libl, Lwów, 20 XII 1872 r., k. 88; J.P. McKay, dz. cyt., s. 19. Tego typu zapisy włączono do umów koncesyjnych na budowę i użytkowanie tramwajów konnych m.in. w Warszawie i Krakowie; por. T. Latos, dz. cyt., s. 272; D. Walczak, dz. cyt., s. 81.

${ }^{58}$ DALO, f. 3, op. 1, sp. 4774, Sprawozdanie komisji elektrycznej, wzmocnionej delegatami sekcji finansowej w sprawie wykupna lwowskiego tramwaju konnego, Lwów, 14 VI 1904 r., k. 29v (s. 6).

${ }^{59} Z$ rady miejskiej (dnia 9 października), „Słowo Polskie”, 9 X 1903, s. 2.

${ }^{60}$ Sz., Wykupno tramwaju konnego, „Słowo Polskie”, 27 V 1903, s. 1-2. 
na zakup tramwaju konnego za kwotę 940 tys. koron ${ }^{61}$. Na podstawie umowy zawartej 7 VII $1906 \mathrm{r}$. władze miasta uroczyście przejęły majatek Lwowskiej Kolei Konnej 16 XI 1906 r. ${ }^{62}$

\section{Próby wdrożenia rozwiązań konkurencyjnych wobec tramwaju konnego}

Chcac obniżyć wydatki przedsiębiorstw tramwajowych, inwestorzy poszukiwali $\mathrm{w}$ latach siedemdziesiątych XIX w. wydajnego napędu mechanicznego. Takim zdawał się być napęd parowy, który adaptowano wówczas na użytek tramwaju ${ }^{63}$. W lutym 1888 r. Towarzystwo Akcyjne Kolei Lwowsko-Bełżeckiej złożyło miastu ofertę wykonania tramwaju parowego ze stacji swojej linii kolejowej w Kleparowie do stacji mającej powstać przy szkole św. Anny na ul. Kazimierzowskiej. Zgodnie z dotychczasowa praktyką radni polecili dyrektorowi Miejskiego Urzędu Budowniczego Juliuszowi Hochbergerowi (1840-1905) udać się do Wiednia i Brna, by tam zapoznał się z funkcjonowaniem przedsiębiorstw tramwajów parowych i rozeznał, czy podobna inwestycja może być korzystna dla Lwowa ${ }^{64}$. Uchwała z 5 VII 1888 r. radni uznali, że tramwaj parowy „łączyć mający wnętrze miasta z dworcami wszystkich niemal kolei we Lwowie, odpowiada interesom publicznym"65. Podobnie jak w innych miastach, inwestor chciał połączyć tramwajem stacje kolejowe ze Śródmieściem, a następnie z magazynami, koszarami wojskowymi i zakładami przemysłowymi. Tramwaj o mocnym napędzie parowym miał być intensywnie wykorzystywany nie tylko do przewozu osób, ale także towarów. Projekt opracowany przez inż. Gustawa Geyera przewidywał wykonanie trzech linii, w tym jednej do Zakładów Przetwórstwa Tytoniowego

${ }^{61}$ DALO, f. 3, op. 1, sp. 4774, Sprawozdanie komisji elektrycznej, wzmocnionej delegatami sekcji finansowej w sprawie wykupna lwowskiego tramwaju konnego, Lwów, 14 VI 1904 r., k. 31v (s. 10); J. Szajner, M. Rechłowicz, dz. cyt., s. 44.

${ }^{62}$ DALO, f. 3, op. 1, sp. 5176, Protokół z 27 XI 1906 r., spisany tegoż dnia w biurze zarządu Kolei Konnej we Lwowie przy ul. Bema l. 10, k. 15-16v.

${ }^{63}$ J.P. McKay, dz. cyt., s. 27-34.

${ }^{64} \mathrm{~W}$ Wiedniu linie tramwaju parowego uruchomiono w 1883 r., w Brnie zaś inwestor zrezygnował w 1884 r. z wykorzystywania koni na rzecz zastosowania napędu parowego; zob. Die Strassenbahnen Österreich-Ungarns, „Zeitschrift für gesamte Lokal und Straßenbahnwesen" 4, 1885, s. 114-115; P. Liez, dz. cyt., s. 137.

${ }^{65}$ K. Ostaszewski-Barański, dz. cyt., s. 226; Sprawozdanie prezydenta król. stot. miasta Lwowa [E. Mochnackiego] z trzechletniej czynności Reprezentacji Miejskiej i Magistratu (1886, 1887 i 1888) wygtoszone na posiedzeniu petnej Rady [miejskiej] dnia 19 stycznia 1889, Lwów 1892, s. 10. 
w Winnikach ${ }^{66}$. Inżynier Józef Szczepaniak podkreślił, że choć tramwaj parowy wymagał zainwestowania kapitału w lekkie lokomotywy i tory $\mathrm{z}$ całkowicie stalowymi, walcowanymi szynami, to w eksploatacji był do $40 \%$ tańszy od tramwaju konnego ${ }^{67}$. Choć zarzą Kolei Lwowsko-Bełżeckiej uzyskał w 1888 r. koncesję rządową na wybudowanie jednej linii tramwaju parowego, to inwestycji tej nie zrealizowano ${ }^{68}$. Negocjacje w sprawie wykonania tramwaju parowego były wykorzystywane przez urzędników do udowodnienia STT, że miasto jest w stanie wprowadzić do Lwowa konkurencyjnego przewoźnika ${ }^{69}$.

Przed otwarciem Powszechnej Wystawy Krajowej udało się zwiększyć dostępność usług przewozu osób, choć realizowano je anachronicznym środkiem transportu. 13 II 1892 r. Tadeusz Umański uzyskał od miasta koncesję na prowadzenie przedsiębiorstwa omnibusów. Realizował regularne kursy sześcioma pojazdami w okresie od wiosny do jesieni na trzech trasach: pl. Halicki - Park Kilińskiego, pl. Cłowy - Łyczaków, pl. Gołuchowskich - dworzec c.k. Kolei Państwowych ${ }^{70}$. Pierwsze dwie wymienione trasy stanowiły uzupełnienie transportu tramwajowego, ostatnia zaś była dla niego konkurencja. Z tego powodu Lwowska Kolej Konna usiłowała zabronić przedsiębiorcy przejazdu ulicami Gródecka i Kazimierzowska, uzasadniając to względami bezpieczeństwa ruchu ${ }^{71}$. $\mathrm{Na}$ żądanie Namiestnictwa Galicji zmieniono trasę przejazdu do dworca kolejowego. Przewozy omnibusem realizowano spod gmachu Galicyjskiej Kasy Oszczędności przez ulice Jagiellońską (ob. W. Hnatiuka) i H. Kołłątaja (ob. M. Mencyńskiego) do ul. Kazimierzowskiej. W grudniu 1892 r. lwowski magistrat zatwierdził regulamin jazdy omnibusu do dworca

66 Szczegółowo zamierzenia wykonania tramwaju parowego we Lwowie opisuja M. Rechłowicz, J. Szajner, dz. cyt., s. 99-101; J. Szajner, M. Rechłowicz, dz. cyt., s. 54-59. ${ }^{67}$ J. Szczepaniak, Tramwaj parowy we Lwowie, „Czasopismo Techniczne” (Lwów) 8, 1890, nr 16-17, s. 180-181, 188; Tramwaj parowy we Lwowie, „Kurier Lwowski”, 14 IV 1888 , s. 2.

${ }_{68}$ Obwieszczenie Ministerstwa Handlu z dnia 19 kwietnia 1893 roku, o wygaśnięciu koncesji na kolej miejscowa Lwów-Kleparów - Lwów Miasto, „Dziennik Ustaw Państwa dla królestw i krajów w Radzie Państwa reprezentowanych" 1893, nr 67, s. 147; Tramway na janowskiem, „Słowo Polskie”, 5 I 1897, s. 2.

${ }_{69}$ T. Merunowicz, Kilka spraw lwowskich - tramwaje, „Gazeta Narodowa”, 20 VII 1892, s. 1.

${ }^{70}$ CDIAU-L, f. 146, op. 68, sp. 2612, Sprawozdanie dyrektora policji lwowskiej do c.k. Namiestnictwa galicyjskiego, Lwów, 3 XI 1892 r., k. 6r-v; tamże, Prezydent miasta Lwowa do c.k. Namiestnictwa galicyjskiego, Lwów, 24 X 1892 r., k. 71; Przewodnik po Lwowie i Powszechnej Wystawie Krajowej wydany przez Towarzystwo dla Rozwoju i Upiększania miasta, Lwów 1894, s. 4.

71 CDIAUL, f. 146, op. 68, sp. 2612, Sprawozdanie dyrektora policji lwowskiej do c.k. Namiestnictwa galicyjskiego, Lwów, 3 XI 1892 r., k. 7v. 
kolejowego z takimi samymi opłatami za przejazd, jak tramwajem konnym $^{72}$. Przedsiębiorstwo to zdołało się utrzymać na rynku tylko ponad rok, po czym zakończyło swoją działalność.

\section{Era tramwaju elektrycznego}

W 1879 r. podczas Wystawy Przemysłowej w Berlinie Werner Siemens (1816-1892) wystawił kolejkę o napędzie elektrycznym. Pomimo dużego zaciekawienia zwiedzających nie spodziewano się wówczas, że może ona zostać zastosowana na większa skalę w transporcie. Gdy 4 lata później Siemens zaprezentował swoją kolejkę na Wystawie Światowej w Chicago, wkrótce w USA rozpoczęła się intensywna adaptacja napędu elektrycznego do transportu tramwajowego ${ }^{73}$. Podczas gdy w Europie w latach 1881-1889 uruchomiono zaledwie cztery linie tramwaju elektrycznego, to w Stanach Zjednoczonych łączna długość linii tramwajów elektrycznych wynosiła w 1890 r. $4037 \mathrm{~km}^{74}$.

Podobnie jak w przypadku tramwajów konnych, wykonanie linii tramwajów elektrycznych na przełomie lat osiemdziesiątych i dziewięćdziesiątych było na ogół inicjatywą spółek, które starały się przekonać miejskie samorządy do nieznanej formy napędu. Wdrażanie tego innowacyjnego systemu poruszania wagonów tramwajowych hamowały obawy związane z zagrożeniem porażenia ludzi energią elektryczna, a także niechęć do instalowania w przestrzeni miast „nieestetycznej” napowietrznej trakcji elektrycznej. Samorządy miejskie w Europie wykazywały w tym czasie spora ostrożność w podejmowaniu decyzji o dopuszczaniu do uruchomienia tramwaju elektrycznego. W publikowanych wówczas licznych opracowaniach fachowych inżynierzy zajmujący się problematyką elektryczności zwracali uwagę, że koszty utrzymywania tramwaju elektrycznego były w miastach USA i Francji nawet o połowę niższe niż tramwaju konnego, co dawało szansę na zwrot poniesionych nakładów, zwłaszcza że malały one jeszcze w miarę rozbudowy linii tramwajowych ${ }^{75}$.

${ }^{72}$ Tamże, Odpis odezwy magistratu miasta Lwowa do c.k. Dyrekcji Policji, Lwów, 28 XII 1892 r., k. 38-39v; Przedsiębiorstwo omnibusów, „Gazeta Lwowska”, 27 IX 1892, s. 4.

73 J.P. McKay, dz. cyt., s. 37-38.

74 J. Baumann, Jak się obecnie przedstawia kwestia elektrycznych kolei?, „Czasopismo Techniczne” (Kraków) 5, 1891, nr 18-19, s. 217; T. Ruśkiewicz, Trakcja elektryczna $w$ miastach, „Przegląd Techniczny” 39, 1901, nr 18-30, s. 157.

75 T. Ruśkiewicz, dz. cyt., s. 158; J.P. McKay, dz. cyt., s. 58-61; B. Schmucki, The Machine in the City. Public Appropriation of the Tramway in Britain and Germany 1870-1915, „Journal of Urban History” 38, 2012, nr 6, s. 1070-1071. 
Do szybkiego przełamania wymienionych obaw doprowadziły wystawy, często wówczas organizowane w większych miastach Europy i USA. Podczas tych imprez zazwyczaj obecne były firmy produkujące urządzenia wytwarzające energię elektryczna. Jak wykazała Beate Binder, przełomowa była Wystawa Elektryczna we Frankfurcie nad Menem zorganizowana w $1891 \mathrm{r}$. Zaprezentowano tam różnorakie możliwości wytwarzania, dostarczania i wykorzystania elektryczności, w tym tramwaj elektryczny ${ }^{76}$. Wówczas elektryczność była popularyzowana w mass mediach, jako najbardziej pożądana cecha „miasta nowoczesnego". Napęd elektryczny zapewniał to, czego brakowało tramwajom konnym - „szybkość, pewność i wydatność”. Ponadto był tańszy w eksploatacji, gdyż w ogóle nie wymagał utrzymywania koni, nie powodował tėz zanieczyszczania ulic odchodami tych zwierząt, a więc był urządzeniem w pełni „higienicznym”77. Spółki, które wkrótce uruchomiły tramwaje elektryczne, mogły od razu czerpać zyski z tego przedsięwzięcia. Dlatego mimo początkowego sceptycyzmu elektryfikacja europejskich miast po 1893 r. była dynamicznym zjawiskiem, które dokonało się w czasie ponad jednej dekady.

Zamysł zastosowania elektryczności jako źródła napędu dla tramwajów we Lwowie był nietypowy w tym sensie, że był inicjatywą władz samorządowych. W grudniu 1891 r. zlecono dyrektorowi Miejskiego Urzędu Budowniczego Juliuszowi Hochbergerowi i profesorowi elektrotechniki lwowskiej c.k. Szkoły Politechnicznej Romanowi Dzieślewskiemu (1863-1924) podjęcie studiów nad zagadnieniem funkcjonowania tramwajów elektrycznych w miastach. Fachowcy ci zapoznali się z ich użytkowaniem w Wiedniu, Pradze, Berlinie i Hamburgu ${ }^{78}$. W sprawozdaniu przedłożonym radnym w marcu 1892 r. wykazali we wnioskach końcowych, że tramwaj elektryczny odpowiada oczekiwanym we Lwowie wymogom na intensywne i tanie usługi transportu publicznego, dajac przy tym uzasadnione podstawy do ekonomicznego sukcesu

${ }^{76}$ B. Binder, Elektrifizierung als Vision. Zur Symbolgeschichte einer Technik im Alltag, Tübingen 1999 (Untersuchungen des Ludwig-Uhland-Instituts der Uniwersität Tübingen im Auftrag der Tübingner Vereinigung für Volkskunde, 89), s. 103-107; por. tė̇ W. Bärlocher, Von der internationalen electrotechnischen Ausstelung, „Zeitschrift für gesamte Lokal und Straßenbahnwesen” 10, 1891, s. 123-128.

77 E. Hauswald, dz. cyt., s. 133; B. Binder, dz. cyt., s. 111-113.

${ }^{78}$ R. Dzieślewski, J. Hochberger, Sprawozdanie w sprawie budowy kolei elektrycznej $w$ mieście Lwowie, Lwów 1892, s. 3; A. Kryżaniwskij, Prąd stały czy przemienny. Jak to było na poczatku elektryfikacji Lwowa, „Zeszyty Naukowe Wydziału Elektrotechniki i Automatyki Politechniki Gdańskiej” 43, 2015, s. 123; J. Szajner, M. Rechłowicz, dz. cyt., s. 65-66. 
przedsięwzięcia ${ }^{79}$. Sceptycyzm niektórych radnych wobec planowanej inwestycji starał się przełamać profesor lwowskiej c.k. Szkoły Politechnicznej Roman Gostkowski (1837-1912). W końcu września 1892 r. wygłosił on w lwowskim ratuszu odczyt, w którego konkluzji uznał „koleje konne, jako instytucje przeżywającą się - elektryczne, jako przedsiębiorstwo rentowne, w pełni rozwoju będące" ${ }^{80}$. Na posiedzeniu rady miejskiej 28 IX 1892 r. na wniosek radnego Andrzeja Gołąba (1837-1903) zdecydowano, że przed otwarciem Powszechnej Wystawy Krajowej należy uruchomić we Lwowie linie tramwaju elektrycznego ${ }^{81}$.

W grudniu $1892 \mathrm{r}$. lwowski magistrat przedłożył do zatwierdzenia Namiestnictwa opracowane przez Hochbergera i Dzieślewskiego plany wykonania na ulicach miasta torów tramwajowych i napowietrznej trakcji elektrycznej. Główna linia miała łączyć dworzec c.k. Kolei Państwowych z Łyczakowem. Tory o walcowanych szynach stalowych i rozstawie 1000 mm zamierzano ułożyć na ulicach: L. Sapiehy (ob. S. Bandery) i M. Kopernika. Przy gmachu żandarmerii na ul. M. Kopernika planowano wykonać jednotorową bocznicę dojazdową do zajezdni przy ul. Pełczyńskiej (ob. skrzyżowanie ul. D. Witowskiego i Bohaterów Majdanu). Z ul. M. Kopernika główna linia miała skręcić w ul. J. Słowackiego przy gmachu Poczty Głównej, następnie prowadzić ul. Sykstuską (ob. P. Doroszenki), przecinajacc ul. Karola Ludwika i Wały Hetmańskie, kierować się pl. Kapitulnym do Rynku i następnie ul. Ruska, Wałami Gubernatorskimi, ul. S. Czarnieckiego (ob. W. Wynnyczenki) miała przebiegać ul. Łyczakowską (łącznie 5,95 km), wraz z krótkim jednotorowym odgałęzieniem wzdłuż ul. św. Piotra (ob. I. Miecznikowa) pod bramę główna Cmentarza Łyczakowskiego. Druga linia miała odchodzić od głównej na Wałach Hetmańskich. Dalej prowadziła przez pl. Mariacki, przecinała tory tramwaju konnego na pl. Halickim i skręcała w ul. Stefana Batorego (ob. Kniazia Romana). Następnie miała przebiegać ulicami Pańską i M. Zyblikiewicza (ob. I. Franki), by kierować się ulicą św. Zofii (ob. I. Franki) pod główną bramę terenów wystawowych (zob. mapa 1) ${ }^{82}$.

${ }^{79}$ R. Dzieślewski, J. Hochberger, dz. cyt., s. 27-28; J. Hickiewicz, P. Sadłowski, Roman Dzieślewski: pierwszy polski profesor elektrotechniki i jego wspótpracownicy, Warszawa-Rzeszów-Tarnów-Gliwice-Opole 2014, s. 77-80; A. Kryżaniwskij, dz. cyt., s. 124.

${ }^{80}$ F. Dobrzyński, W sprawie budowy kolei elektrycznej we Lwowie, „Czasopismo Techniczne" (Lwów) 10, 1892, nr 10, s. 85.

${ }^{81}$ Rada miejska, „Gazeta Narodowa”, 28 IX 1892, s. 2.

${ }^{82}$ CDIAUL, f. 146, op. 68, sp. 3271, Projekt der elektrischen Stadtbahn, Detail-Situation der Linie [Hauptlinie-Linie d], oprac. R. Dzieślewski, J. Hochberger [Lwów 1892], k. 7-10. 
Na podstawie zatwierdzonego przez Namiestnictwo projektu wykonania linii tramwajowych ${ }^{83} \mathrm{w}$ końcu maja 1893 r. urzędnicy magistratu rozpoczęli starania o wiążącą uchwałę rady miejskiej w sprawie realizacji inwestycji. Sprawozdawca komisji elektrycznej Zygmunt Kędzierski (1839-1924) wzbudził emocjonującą dyskusję wśród radnych, rekomendując wykonanie infrastruktury i prowadzenie przedsiębiorstwa tramwajowego przez miasto ${ }^{84}$. Temu wnioskowi przeciwny był prof. Roman Gostkowski, który wprawdzie przyznał, że Lwów ma stanowczo za mała sieć kolei miejskiej, a tramwaje elektryczne w innych miastach sa przedsięwzięciem zyskownym, lecz miał wątpliwości, czy uda się utrzymać zadowalające dochody z takiego przedsiębiorstwa we Lwowie ${ }^{85}$. Niektórzy radni usiłowali przekonywać, że w przypadku tej inwestycji „straty są wykluczone, będą zyski, które miasto a nie obcy zagarnąć powinno"86. Większość jednak oponowała, że miasto chce zaangażować własne fundusze w ryzykowne przedsięwzięcie, aby „pokazać się” na wystawie, podczas gdy zaniedbane pozostaną inne palące kwestie, takie jak choćby brak centralnej kanalizacji i wodociagu ${ }^{87}$. Henryk Rewakowicz (1837-1907) porównał przedsięwzięcie do „zamków Potiomkina, służących jeno za dekorację ubóstwa gminy”. Stąd uchwałą z 27 V 1893 r. rada miejska zdecydowała się zlecić wykonanie tramwaju elektrycznego i prowadzenie przedsiębiorstwa wyspecjalizowanej firmie ${ }^{88}$. Na tej podstawie 21 VI 1893 r. c.k. Ministerstwo Kolei Żelaznych przyznało gminie miasta Lwowa koncesję na wykonanie „miejskiej kolei elektrycznej”89.

Spośród pięciu ofert wykonania tramwaju elektrycznego najkorzystniejsze okazały się te przedłożone miastu przez niemieckie koncerny elektrotechniczne. 4 VII 1893 r. przybyli do Lwowa pełnomocnicy wiedeńskich oddziałów Allgemeine Elektrizitäts-Gesellschaft (AEG)

${ }^{83}$ Powołana przez Namiestnictwo „komisja obchodowa”, zgodnie ze stosowanymi procedurami, zaakceptowała 18-22 IV 1893 r. projektowany przebieg linii tramwajowych; zob. CDIAUL, f. 146, op. 68, sp. 3276, Protokoll begonnen am 18. April 1893 [...], Lemberg, 22 IV 1893 r., k. 40-60v.

${ }^{84}$ Rada miasta Lwowa (posiedzenie dnia 25 maja), „Gazeta Lwowska”, 27 V 1893, s. 4.

${ }^{85}$ Kolej elektryczna, „Gazeta Narodowa”, 24 IV 1893, s. 2; Z rady miejskiej, „Gazeta Narodowa”, 26 V 1893, s. 2; R. Gostkowski, Czy trzeba nam kolei elektrycznej, „Gazeta Narodowa”, 11 VII 1893, s. 1.

${ }^{86}$ Sprawa tramwaju elektrycznego, „Kurier Lwowski”, 26 V 1893, s. 4.

${ }^{87} Z$ lwowskiej Rady miejskiej, „Kurier Lwowski”, 27 V 1893, s. 4-5.

${ }^{88}$ Rada miasta Lwowa (posiedzenie 27 maja), „Gazeta Lwowska”, 30 V 1893, s. 4-5.

${ }^{89}$ CDIAUL, f. 146, op. 68, sp. 3276, Konzessionsbestimmungen für die mit elektrischer Kraft zu betreibende Strassenbahn im Gemeindegebiete der Stadt Lemberg, k. $124-128$. 
i Siemens \& Halske ${ }^{90}$. AEG oferowało wykonanie elektrowni i linii tramwajowych oraz prowadzenie przedsiębiorstwa tramwajowego na własny rachunek przez rok. Po tym czasie miasto mogło zdecydować się na wykupienie tramwaju lub wejście w spółkę z inwestorem. Pełnomocnicy Siemens \& Halske dostosowali się do oferty AEG, lecz zaoferowali prowadzenie przedsiębiorstwa na własny rachunek przez 2 lata. Radni zaakceptowali tę ofertę na posiedzeniu 14 VII $1893 \mathrm{r}^{91}$

Po 2 latach użytkowania władze Lwowa mogły „pozostawić kolej do prowadzenia ruchu firmie Siemens \& Halske na jej zysk lub stratę". W przypadku zysku większego niż 6\% w skali roku inwestor zobowiązany był przekazać połowę uzyskanych dochodów miastu. Miasto mogło także wejść $\mathrm{w}$ spółkę $\mathrm{z}$ inwestorem ${ }^{92}$. Jednak wobec większych niż się spodziewano dochodów radni zdecydowali się skorzystać z trzeciej możliwości, jaką było wykupienie przedsiębiorstwa. Z kapitału pozyskanego z emisji obligacji komunalnych, zgodnie z zapisami umowy, wypłacono Siemens \& Halske równowartość kosztów budowy infrastruktury z doliczeniem 6\% zysku od tej kwoty i dodatkowych kosztów poniesionych w zwiąku z użytkowaniem tramwaju ${ }^{93}$.

Jesienią 1893 i wiosną następnego roku inwestor wykonał tory tramwajowe wraz z napowietrzną trakcją elektryczna. Koncentrowano się na jak najszybszym wybudowaniu linii od dworca kolejowego w kierunku głównej bramy Powszechnej Wystawy Krajowej. Regularny kurs wagonów uruchomiono $31 \mathrm{~V} 1894$ r., zaledwie 5 dni przed otwarciem wystawy ${ }^{94}$. Wykonanie brakującego odcinka głównej linii w kierunku Łyczakowa miało miejsce $\mathrm{w}$ październiku i listopadzie. Po zakończeniu wystawy zdemontowano tory na odcinku od ul. św. Zofii do terenów wystawowych. Pozyskane w ten sposób szyny użyto do położenia torów w ul. Łyczakowskiej (zob. mapa 1). Regularny ruch wagonów uruchomiono na tej ulicy 12 XII $1894 r{ }^{95}$ Energię elektryczną potrzebną

${ }_{90}$ Kolej elektryczna we Lwowie, „Kurier Lwowski”, 5 VII 1893, s. 4; J. Szajner, M. Rechłowicz, dz. cyt., s. 68-69.

${ }^{91}$ DALO, f. 3, op. 1, sp. 4774, Sprawozdanie i wnioski komisji elektrycznej w sprawie wykupna kolei konnej, Lwów, 17 II 1906 r., k. 46r-v (s. 1-2); Z lwowskiej rady miejskiej, „Kurier Lwowski”, 16 VII 1893, s. 4-5.

${ }_{92}$ Kontrakt zawarty $z$ forma Siemens \& Halske o budowe i ruch kolei elektrycznej we Lwowie, Lwów 1894, s. 7-8.

${ }_{93}$ M. Altenberg, S. Kozłowski, Działalność elektryfikacyjna m. Lwowa, Warszawa 1937, s. 3 (nadb. z: „Przegląd Elektrotechniczny” 19, 1937, nr 5).

${ }_{94}$ CDIAUL, f. 146, op. 68, sp. 3276, Protokoll aufgenommen in Lemberg, $28 \mathrm{~V}$ 1894 r., k. 233-234v; tamże, Magistrat król. stoł. miasta Lwowa, Obwieszczenie, Lwów, 30 V 1894 r., k. 236.

${ }_{95}$ DALO, f. 3, op. 1, sp. 4774, Magistrat król. stoł. miasta Lwowa, Obwieszczenie, 
do napędzania wagonów tramwajowych wytwarzano w elektrowni tramwajowej, która wystawiono na miejskiej parceli przy ul. Wuleckiej 1 (ob. A. Sacharowa). Wykonano w niej dwa zespoły agregatów parowo-elektrycznych. Każdy składał się z wodnorurkowego kotła parowego, maszyny parowej o mocy $250 \mathrm{KM}$ i generatora elektrycznego Siemensa, zdolnego wytwarzać prąd o stałym napięciu $500 \mathrm{~V}^{96}$. Na północ od elektrowni wystawiono przy ul. Pełczyńskiej zajezdnię tramwajowa (zob. il. 1) zdolną garażować 16 wagonów, wyprodukowanych przez Gracką Fabrykę Budowy Wagonów i Maszyn (przedtem J. Weitzer) ${ }^{97}$.

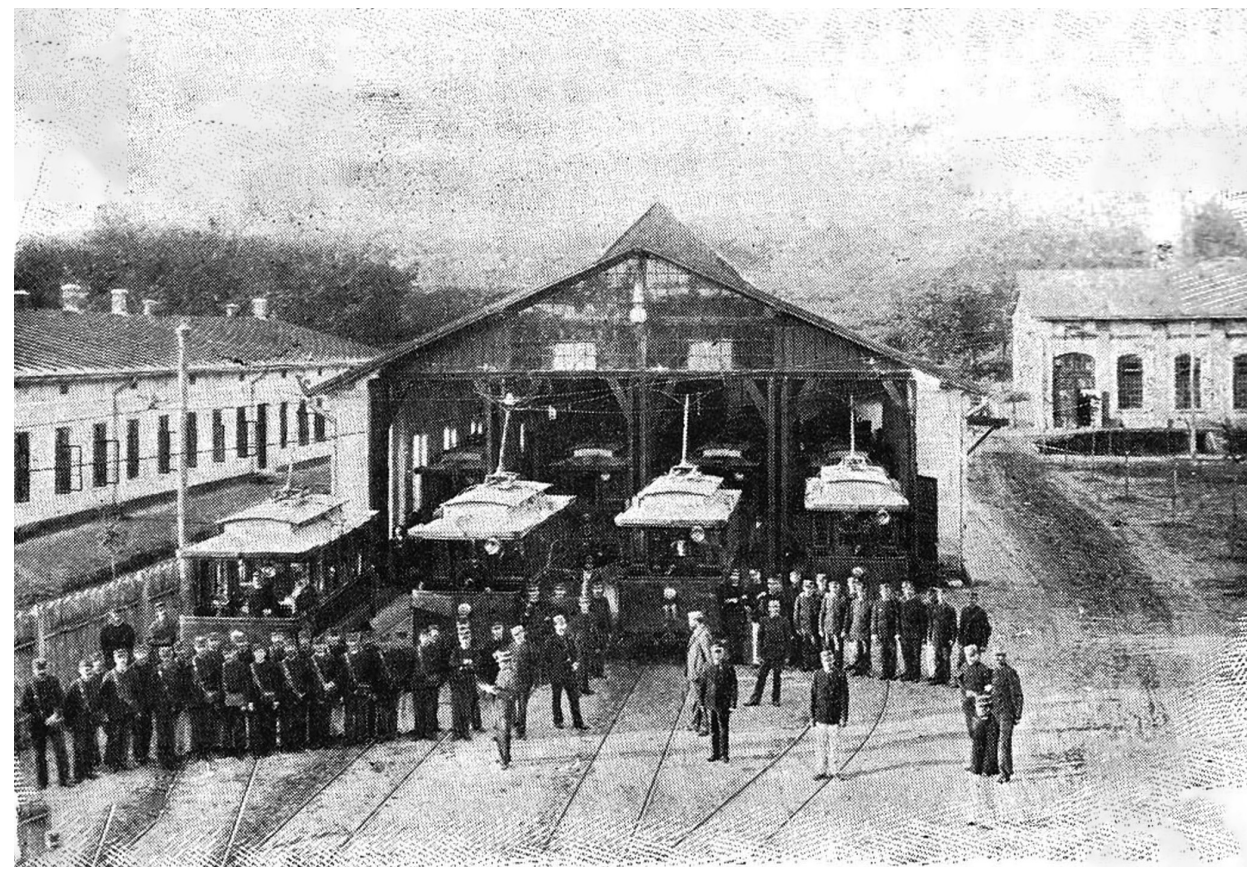

Il. 1. Widok zajezdni tramwaju elektrycznego przy ul. Pełczyńskiej, fot. wykonana z okazji otwarcia ruchu w końcu maja 1894 r.; źródło: J. Tomicki, Ze statystyki miejskich zakładów elektrycznych we Lwowie, Lwów 1912, s. 2.

Lwów, 11 XII 1894 r., k. 60; CDIAUL, f. 146, op. 62, sp. 3277, Situation: Hauptlinie Bahnhof Łyczkover Vorstadt vom Klm 3,0 bis zum Ende, k. 6.

${ }_{96}$ CDIAUL, f. 146, op. 68, sp. 3276, Protokoll aufgenommen in Lemberg, $28 \mathrm{~V}$ 1894 r., k. 235r-v; M. Altenberg, S. Kozłowski, dz. cyt., s. 3.

${ }^{97}$ CDIAUL, f. 146, op. 68, sp. 3276, Protokoll aufgenommen in Lemberg, 28 V 1894 r., k. 235v. O budowie kompleksu zajezdni i elektrowni tramwajowej wraz z wyposażeniem technicznym zob. А. Кріжанівський, Історія електрифікації Львівщини, Львів 2015, s. 35; T. Dywan, Od „szkoły berlińskiej” do secesji..., s. 178-182; J. Szajner, M. Rechłowicz, dz. cyt., s. 79-81. 
Należy podkreślić, że w porównaniu do innych środkowoeuropejskich miast we Lwowie stosunkowo szybko zdecydowano się uruchomić tramwaj elektryczny. Przezornie zastosowano sprawdzona już w kilku miastach europejskich metodę weryfikacji, czy taka innowacja jak elektryczność przyjmie się na miejscu. Linie tramwaju elektrycznego, podobnie jak to miało miejsce w Bremie (1890), Lyonie (1894) i przede wszystkim w Pradze (1891), wykonano z myślą o obsłudze publiczności podczas trwania ważnych wystaw. Przykład Bremy oddziaływał bezpośrednio na władze samorządowe Hamburga, które bez pretekstu organizowania wystawy zdecydowały się wykonać tramwaj elektryczny. Można takie postępowanie potraktować jako rodzaj psychologicznego działania majacego przekonać sceptyków, którzy w zwyczajnych warunkach nie zdecydowaliby się na podjęcie ryzyka. Zresztą nie było ono wcale duże, skoro trudu sfinansowania inwestycji w Bremie i Lyonie podją się koncern Thomson Hudson, a linię w Pradze wykonał František Kř́žík (1847-1941) ${ }^{98}$.

Po wykupieniu od inwestora przedsiębiorstwa Lwowskiej Kolei Elektrycznej, chcąc oświetlić elektrycznie nowy gmach Teatru Miejskiego, władze Lwowa zdecydowały się na rozbudowę elektrowni. Powiększono wówczas maszynownię, aby pomieścić w niej dodatkowy agregat parowo-elektryczny, złożony z dwóch wodnorurkowych kotłów parowych, turbiny parowej systemu Parsonsa o mocy $500 \mathrm{KM}$ i generatora elektrycznego Siemensa ${ }^{99}$. W latach 1905-1906 miasto wbudowało kolejną zajezdnię dla pomieszczenia zwiększającej się liczby wagonów tramwajowych ${ }^{100}$. Od 1903 r. miasto zamawiało wagony tramwajowe w Pierwszym Galicyjskim Towarzystwie Akcyjnym Budowy Wagonów i Maszyn w Sanoku (przedtem K. Lipiński). Fabryka sanocka rozpoczęła wówczas produkcję wagonów tramwajowych o napędzie elektrycznym, dostarczanych najpierw dla Lwowa, a później Wiednia, Ostrawy i Krakowa (zob. il. 3) ${ }^{101}$.

Linie tramwaju elektrycznego wykonane w $1894 \mathrm{r}$. nie były rozbudowywane przez 12 lat. Było to spowodowane skonfliktowaniem się miasta

98 J.P. McKay, dz. cyt., s. 109-110; J. Kohout, J. Vančura, Praha 19. a 20. století. Technicke proměny, Praha 1986, s. 84-85.

${ }_{99}$ J. Tomicki, Ze statystyki miejskich zakładów elektrycznych we Lwowie, Lwów 1912, s. 3; M. Altenberg, S. Kozłowski, dz. cyt., s. 4; A. Кріжанівський, dz. cyt., s. 42.

100 CDIAUL, f. 146, op. 68, sp. 3278, Magistrat miasta Lwowa do c.k. Ministerstwa Kolei Żelaznych w Wiedniu, Lwów, 16 X 1906 r., k. 90r-v; T. Dywan, Od „szkoty berlińskiej" do secesji..., s. 200.

${ }^{101}$ DALO, f. 3, op. 1, sp. 4082, Dyrekcja Miejskich Kolei Elektrycznych do III departamentu magistratu, Lwów, 26 V 1903 r., k. 48r-v; Nowe wozy tramwajowe, „Słowo Polskie", 4 XII 1903, s. 2; Z. Osenkowski, Od kottów po pojazdy szynowe Fabryki Sanockiej, „Rocznik Sanocki” 7, 1995, s. 122, autor ustalił wykonanie 75 wagonów tramwajowych dla Lwowa. 
z STT, o czym była już mowa. Po wykupie przedsiębiorstwa Lwowskiej Kolei Konnej władze miasta przystapiły do realizacji projektu rozszerzenia linii tramwajowych. $\mathrm{W}$ opracowanym w lwowskim magistracie wniosku wskazywano radnym, że pomimo konkurencji tramwaju konnego oraz poprowadzenia linii bocznymi ulicami, to tramwaj elektryczny okazał się przedsięwzięciem zyskownym. Ponadto przewidywany wzrost liczby przejazdów tramwajami elektrycznymi we Lwowie i innych wielkich miastach monarchii skłaniał do rychłego podjęcia inwestycji ${ }^{102}$. 28 VIII 1906 r. miejscy urzędnicy wszczęli procedurę uzyskania koncesji rządowej na użytkowanie zarówno istniejących, jak i mających powstać linii tramwajowych, zgodnie z regulacją ustawy państwowej „o kolejach niższego rzędu" z 31 XII 1894 r. W zamian za wykonanie sieci tramwajowej służącej „podniesieniu rozwoju miasta i jego martwych dotąd przedmieśćc chciano uzyskać zwolnienie od podatków i opłat z tytułu budowy i użytkowania kolei lokalnej na 15 lat $^{103}$. Dopełnienie wymaganych prawem procedur na miejscu (komisyjne zatwierdzenie tras przebiegu linii przez Namiestnictwo, wydanie pozwoleń na budowę, uzyskanie finansowania), jak i zatwierdzenie inwestycji przez c.k. Ministerstwo Kolei Żelaznych zajęło niespełna 18 miesięcy. Zgodnie z wnioskiem magistratu, po akceptacji rady miejskiej, 11 II 1908 r. udzielono gminie miasta Lwowa nowej koncesji na „budowę i przeprowadzenie sieci jednolitej waskotorowej miejskiej kolei elektrycznej”"104.

W trakcie dopełniania procedur zmierzających do uzyskania koncesji miastu udało się wykonać dwie jednotorowe linie tramwajowe. Pomimo niesprzyjajacej pory roku, na przełomie 1906 i 1907 r. położono tor tramwajowy od ul. L. Sapiehy przez ulice Krzyżowa (ob. Generała Czuprynki) i 29 Listopada (ob. J. Konowalca). Regularne kursy wagonów uruchomiono 18 I 1907 r. ${ }^{105}$ Ze względu na planowane otwarcie wystawy lekarsko-przyrodniczej, która miała się odbyć w zabudowaniach po Powszechnej Wystawie Krajowej, władze miasta zdecydowały

102 DALO, f. 3, op. 1, sp. 5095, Sprawozdanie komitetu wybranego z łona komisji elektrycznej dla zbadania projektu rozszerzenia sieci kolei elektrycznej i zaopatrzenia m. Lwowa w energię elektryczna, Lwów, 18 X 1906 r., k. 1-10.

103 AGAD, zesp. 310, sygn. 362a, Magistrat miasta Lwowa do c.k. Ministerstwa Kolei Żelaznych, Lwów, 28 VIII 1906 r., s. 280-289; Ustawa $z$ dnia 31 grudnia 1894, o kolejach niższego rzędu, „Dziennik Ustaw Państwa dla królestw i krajów w Radzie Państwa reprezentowanych" 1895, nr 2, s. 6-12.

${ }^{104}$ Obwieszczenie c.k. Ministerstwa Kolei Żelaznych z dnia 11 lutego 1908, dotyczace koncesjonowania sieci waskotorowych kolejek elektrycznych we Lwowie, „Dziennik Ustaw Państwa dla królestw i krajów w Radzie Państwa reprezentowanych” 1908, nr 41, s. 67.

105 AGAD, zesp. 310, sygn. 362a, Protokoll aufgenommen am 17. Jänner 1907 in Lemberg [...], s. 241-249; Tramway na Bajkach, „Gazeta Lwowska”, 19 I 1907, s. 4. 
się ułożyć w końcu maja 1907 r. tor od ul. św. Zofii do bramy wejściowej na wystawę. Regularny kurs wagonów uruchomiono na tej linii 17 VI 1907 r. $^{106}$

W końcu sierpnia 1908 r. przystapiono do likwidacji jednego toru linii tramwaju konnego. $\mathrm{Na}$ jego miejscu wykonano wykopy pod założenie betonowych fundamentów torowiska. Na nich położono jeden tor z kilkoma prowizorycznymi „mijankami”. Tory tramwajowe ułożono ponadto $\mathrm{w}$ ulicach Janowskiej (do rogatki), Zamarstynowskiej (do rogatki) i Nowej Rzeźni (ob. Przemysłowa). Próbna jazda wagonów na wymienionych liniach odbyła się 5-6 listopada, a regularny ruch rozpoczęto 31 XII 1908 r. ${ }^{107}$ Drugi tor linii tramwajowej od dworca kolejowego do rogatki żółkiewskiej oraz w ul. Hetmańskiej wykonano w maju, a regularny ruch wagonów rozpoczęto tam 26 VI $1909 \mathrm{r} .{ }^{108} \mathrm{~W}$ lipcu tegoż roku wykonano tory tramwajowe od ul. Stefana Batorego przez Pańska, J. Kochanowskiego i św. Piotra pod bramę główną Cmentarza Łyczakowskiego. Linię tę oddano do użytku 16 VIII 1909 r. ${ }^{109} 25$ V 1910 r. rozpoczęto regularny kurs wagonów na jednotorowej linii w kierunku Wysokiego Zamku110.

Energii elektrycznej potrzebnej dla napędu wagonów tramwajowych dostarczała jedna z większych elektrowni miejskich w Austro-Węgrzech, wybudowana w latach 1907-1908. Wykonano w niej trzy agregaty parowo-elektryczne (zob. il. 2). Każdy składał się z dwóch kotłów wodnorurkowych, maszyny parowej o mocy $2000 \mathrm{KM}$ i generatora elektrycznego zdolnego wytwarzać prąd przemienny o napięciu 5500 V. Energię elektryczną dostarczano podziemnymi kablami wysokiego napięcia do elektrowni tramwajowej przy ul. Wuleckiej. Ustawiono w niej trzy przetwornice elektromechaniczne. Dzięki nim przy niewielkich stratach energii dokonywano konwersji prądu przemiennego o napięciu $5000 \mathrm{~V}$ na prąd stały o napięciu $500 \mathrm{~V}$. Zasilano nim napowietrzną trakcję tramwajowa, a po obniżeniu napięcia przy pomocy

${ }^{106}$ DALO, f. 3, op. 1, sp. 5096, Magistrat król. stoł. miasta Lwowa: Obwieszczenie, Lwów, 22 VI 1907 r., k. 25r-v.

${ }^{107}$ Próbna jazda, „Gazeta Narodowa”, 5 XI 1908, s. 3; Nowe linie kolei elektrycznej, „Kurier Lwowski”, 5 XI 1908, s. 4; Tramway do Teatru, „Gazeta Narodowa”, 1 I 1909, s. 2.

108 AGAD, zesp. 310, sygn. 362b, Protokoll aufgenommen am 25. Juni 1909 in Lemberg [...], s. 11-17; Tramwaj elektryczny, „Gazeta Narodowa”, 27 VI 1909, s. 2.

109 Tramwaj elektryczny, „Gazeta Narodowa”, 17 VIII 1909, s. 2; Tramwaj elektryczny, „Kurier Lwowski”, 17 VIII 1909, s. 3.

${ }^{110}$ DALO, f. 3, op. 1, sp. 5097, J. Tomicki do magistratu miasta Lwowa, Lwów, 30 IV 1910 r., k. 60r-v; Tramwaj elektryczny na Wysoki Zamek, „Kurier Lwowski”, 6 VIII 1910, s. 4. 


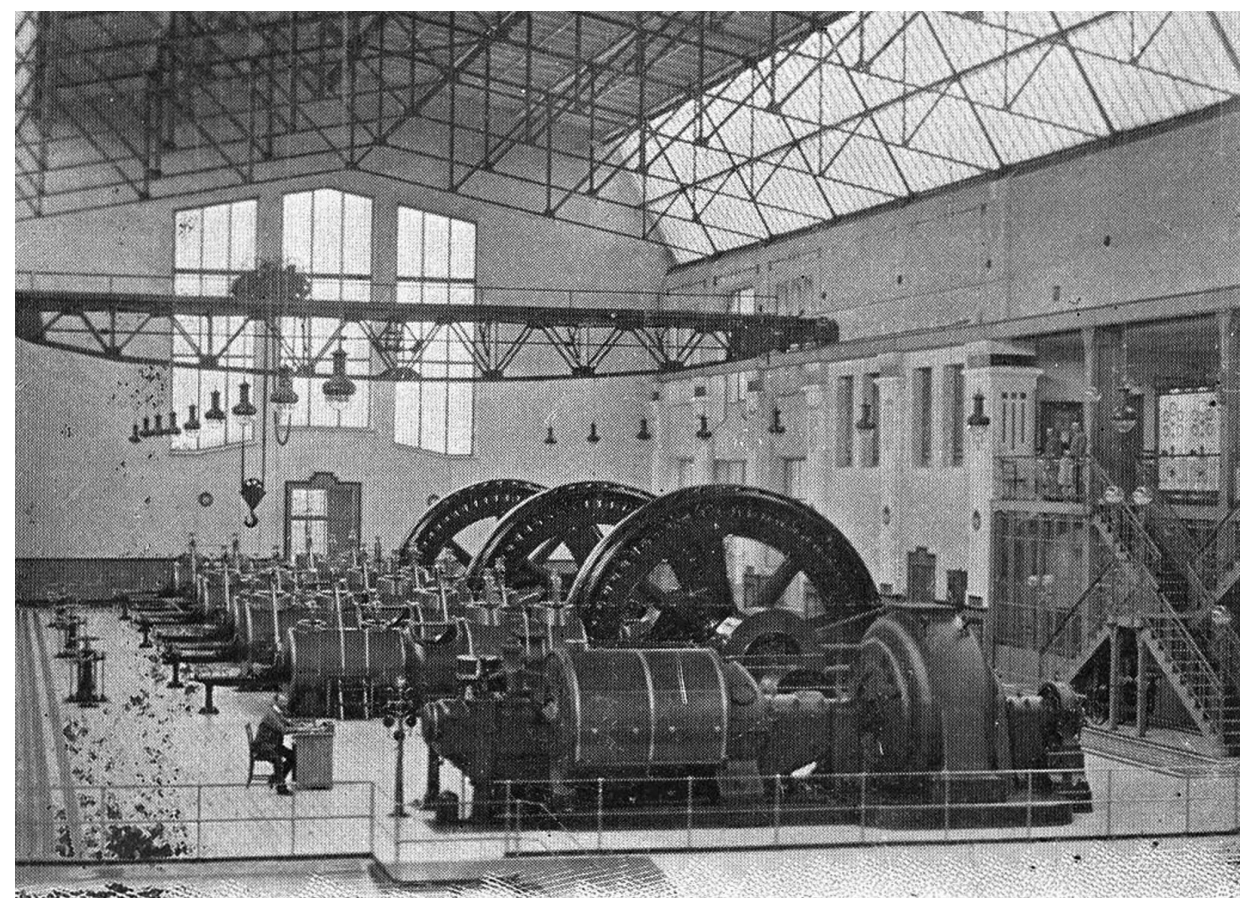

Il. 2. Maszynownia miejskiej elektrowni na Persenkówce: w głębi widoczne trzy agregaty parowo-elektryczne z 1908 r., na pierwszym planie turbogenerator z 1911 r.; źródło: J. Tomicki, Ze statystyki miejskich zakładów elektrycznych we Lwowie, Lwów 1912, s. 9.

transformatorów dwie typy sieci elektrycznej: dla rozprowadzania prądu stałego (rozciagniętą w latach w 1900-1907) i zmiennego (wykonywaną od 1908 r. $)^{111}$.

\section{Konsekwencje wdrożenia transportu tramwajowego dla miasta}

W publikacji wydanej z okazji jubileuszu ćwierćwiecza niezależnego lwowskiego samorządu inżynier Miejskiego Urzędu Budowniczego Michał Kowalczuk (1855-1938) stwierdził, że „te dwa środki ułatwiające komunikację [tramwaj konny i elektryczny - T.D.], przyczyniły się

${ }^{111}$ Ciag dalszy 77-go posiedzenia rady miejskiej dnia 28 lutego, „Dziennik Lwowski. Organ urzędowy gminny król. stoł. miasta Lwowa" 2, 1907, nr 5, s. 134; J. Tomicki, dz. cyt., s. 7-8. O budowie elektrowni na Persenkówce zob. też A. Кріжанівський, dz. cyt., s. 57-60; T. Dywan, Od „szkoty berlińskiej” do secesji..., s. 198-205. 
w wielkim stopniu do rozwoju miasta, czego mamy dowód w powiększaniu się tegoż w kierunku zachodnim [...] lub na północy przy ul. Żółkiewskiej"112. Należy się zastanowić, w jakim stopniu obydwa środki transportu przyczyniły się do rozwoju Lwowa i zmieniły życie jego mieszkańców. Dotychczasowa refleksja historyków w tej kwestii w odniesieniu do innych miast pozwala dostrzec złożoność problemu, który nie daje się sprowadzić do takich prostych wniosków.

Zależność rozwoju sieci tramwajów od industrializacji próbował wyjaśnić Francis W. Carter na przykładzie Pragi. W 1875 r. tramwaj konny wykonała w stolicy Królestwa Czech spółka Eduarda Ottleta. Jednak częstotliwość przejazdów w ostatniej ćwierci XIX w. wzrastała w Pradze nieznacznie, co ze zdumieniem zauważył ów historyk ${ }^{113}$. Pierwsza linia tramwaju konnego uruchomiona w 1865 r. w Wiedniu połączyła Ringstrasse na wysokości Schottentor z przedmieściem Hernals i późniejszym przedłużeniem do Dornbach. Z regularnego połączenia Śródmieścia z urokliwymi przedmieściami, stanowiącymi uczęszczane miejsca wypoczynku, korzystała głównie klasa średnia, o wiele rzadziej zaś wiedeńscy robotnicy, gdyż tramwaj był dla nich zbyt kosztowny ${ }^{114}$. Powyższe przykłady uzmysławiaja, że podobnie jak omnibusy, także tramwaje konne nie były wystarczająco tanim środkiem transportu, aby mógł być dostępny „dla wszystkich”. Większą liczbę przejazdów tramwajami konnymi notowano zazwyczaj latem w niedzielę i dni wolne od pracy. Było to typowe dla tego środka transportu, który stał się tańszą alternatywa dla dorożek. Dopiero kiedy spółki tramwajowe zaczęły prowadzić politykę obniżania ceny za przejazd skutkowało to stopniowym zwiększeniem się liczby klientów ${ }^{115}$.

Barbara Schmucki zauważyła, że przedsiębiorstwa tramwajów konnych rozwijały się dosyć powoli, co kontrastuje z dynamicznie rozwijającymi się ok. 1900 r. przedsiębiorstwami tramwajów elektrycznych. Miejskie samorządy obawiały się udzielać koncesji inwestorom, którzy

${ }_{112}$ M. Kowalczuk, Rozwój terytorialny miasta, w: Miasto Lwów w okresie samorzqdu..., s. 331.

${ }^{113}$ F.W. Carter, Public Transport Development in Nineteenth-Century Prague, w: Economic Development in the Habsburg Monarchy and in the Successor States, red. J. Komlos, New York 1990 (East European Monographs, 280), s. 32-35; zob. też J. Kohout, J. Vančura, dz. cyt., s. 80-81.

${ }_{114}$ P. Liez, dz. cyt., s. 124-125; P. Capuzzo, Transportation System and Urban Space: Vienna 1865-1938, „Jahrbuch für Wirtschaftsgeschichte” 39, 1998, nr 2, s. 153-154; E. Offenthaler, Der öffentliche Verkehr in Wien, w: Budapest und Wien. Technischer Fortschritt und urbanen Aufschwung im 19. Jahrhundert, red. P. Csendes, A. Sipos, Budapest-Wien 2003, s. 123-124.

115 J.P. McKay, dz. cyt., s. 23, 226-228; B. Schmucki, dz. cyt., s. 1065-1066. 
brali pod uwage nie tyle interes publiczny, ile szybki zysk tramwaju konnego. Nie dość, że przejazdy te nie były tanie, to jeszcze w opinii mieszkańców wielu miast tamowały ruch uliczny. Tramwaj był nowym i jeszcze „nieoswojonym” elementem miasta ${ }^{116}$. To spostrzeżenie można odnieść także do Lwowa. Świadczy o tym protest mieszkańców ul. Żółkiewskiej wniesiony w $1881 \mathrm{r}$. do rady miejskiej przeciw planowanej rozbudowie torów tramwajowych. Według mieszkańców tramwaj wręcz uprzykrzał im życie, tamował ruch wozów, będąc przyczyną licznych wypadków na tej ulicy ${ }^{117}$. Można także założyć, że niewielu mieszkańców uchodzącej za biedną tejże dzielnicy mogło korzystać z przejazdów tramwajem konnym ${ }^{118}$.

W 1881 r. Lwowska Kolej Konna odnotowała prawie 1427 tys. przejazdów, co stanowiło 13 przejazdów na każdego mieszkańca. Dziesięć lat później było to już prawie 2178 tys. przejazdów, co stanowiło 17 per capita ${ }^{119}$. Wzrost przejazdów nie dorównywał jednak liczbie ponad 40 przejazdów na mieszkańca odnotowanych w Wiedniu i Budapeszcie. Częstotliwość przejazdów we Lwowie była nieznacznie mniejsza niż w Pradze ${ }^{120}$. W obu tych miastach zadowalajacca dochodowość przedsiębiorstw tramwajowych udało się utrzymać dzięki intensywnie użytkowanym liniom łączącym dworce kolejowe ze śródmieściami.

Tramwaj konny nigdy nie był postrzegany jako szczególnie „nowoczesny” środek transportu - wszakże był ciaggnięty przez konie. W dobie postępującej mechanizacji przełomu wieków takie rozwiązanie wydawało się być „zabytkiem starożytności” ${ }^{21}$. A uruchamiane w tym czasie w miastach USA i Europy tramwaje elektryczne były bardziej komfortowe i szybsze od konnych. Do tego stanowiły osiagalny dla kieszeni robotników środek transportu ${ }^{122}$. Stopniowe obniżanie opłaty za przejazd tramwajem elektrycznym, obserwowane w europejskich metropoliach, zgodnie z przewidywaniami prof. Romana Gostkowskiego nie wystapiło we Lwowie ${ }^{123}$. Cena za przejazd jedną sekcją tramwajem elektrycznym

116 B. Schmucki, dz. cyt., s. 1062-1063.

117 DALO, f. 3, op. 1, sp. 3166, Do świetnej rady miejskiej miasta Lwowa, Lwów, 20 II 1881 r., k. 43v-44. Na podobna sytuację blokowania waskich ulic w centrum Wrocławia przez wagony tramwajowe zwrócił uwagę T. Sielicki, dz. cyt., s. 40-41.

118 J. Lewicki, dz. cyt., s. 39.

119 J. Szajner, M. Rechłowicz, dz. cyt., s. 35 (tab. 35).

${ }^{120}$ R. Gostkowski, Rentowność tramwaju elektrycznego, „Gazeta Narodowa”, 3 VII 1896, s. 2.

${ }^{121}$ Lwowski tramwaj elektryczny, „Lwowianin” 10, 1902, nr 1, s. 8.

122 J.P. McKay, dz. cyt., s. 202; F.W. Carter, dz. cyt., s. 33-35; B. Schmucki, dz. cyt., s. $1073-1074$.

${ }^{123}$ Tramwaj elektryczny, „Gazeta Narodowa”, 28 VI 1893, s. 1. 
i konnym była taka sama w latach 1894-1900 (zob. tab. 1). Niekorzystna dla tramwaju konnego była dopłata, jaka pasażerowie winni byli uiszczać na trasie ze Śródmieścia do dworca kolejowego. Pobierano ją przez wzgląd na warunki trasy, gdyż pod górę ul. Gródeckiej zaprzęgano do wagonu dodatkowego konia. Przypuszczam, że o sukcesie tramwaju elektrycznego we Lwowie zdecydowała szybkość jazdy, komfort podróżowania i nowatorstwo zastosowanego napędu. Tego stanu rzeczy nie zmieniło podwyższenie opłaty za przejazd wprowadzone w końcu grudnia 1900 r. na skutek wzrostu cen węgla kamiennego, używanego do opalania kotłów parowych elektrowni tramwajowej (zob. tab. 1) ${ }^{124}$. Kierownictwu Miejskich Kolei Elektrycznych udało się uniknąc kolejnych podwyżek opłat za przejazd i jednocześnie utrzymać dochodowość przedsiębiorstwa dzięki zastosowaniu do opalania kotłów parowych tańszej ropy naftowej ${ }^{125}$.

Tabela 1. Cena przejazdu tramwajem konnym, elektrycznym i dorożką jednokonną w we Lwowie*

\begin{tabular}{|c|c|c|c|c|c|}
\hline \multirow{3}{*}{$\begin{array}{c}\text { Wybrane } \\
\text { lata }\end{array}$} & \multicolumn{4}{|c|}{ Koszt przejazdu jedną sekcją* } & \multirow{3}{*}{$\begin{array}{c}\text { Koszt przejazdu } \\
\text { bez zatrzymywania } \\
\text { dorożką jednokonną } \\
\text { w obrebie jednej } \\
\text { dzielnicy w ciągu dnia* }\end{array}$} \\
\hline & \multicolumn{2}{|c|}{ Tramwaj konny** } & \multicolumn{2}{|c|}{ Tramwaj elektryczny } & \\
\hline & I klasa & II klasa & I klasa & II klasa & \\
\hline 1880 & 0,10 & 0,08 & - & - & 0,40 \\
\hline 1888 & 0,08 & 0,06 & - & - & 0,40 \\
\hline 1894 & 0,08 & 0,06 & 0,08 & 0,06 & 0,45 \\
\hline 1900 & 0,08 & 0,06 & $0,08 / 0,10$ & $0,06 / 0,08$ & 0,50 \\
\hline 1902 & 0,08 & 0,06 & 0,10 & 0,08 & 0,50 \\
\hline 1910 & - & - & 0,10 & 0,08 & 0,60 \\
\hline
\end{tabular}

Legenda: *ceny podane $\mathrm{w}$ tabeli stanowią równowartość $\mathrm{w}$ koronach austro-węgierskich $(1$ korona $=$ 100 halerzy); ** za przejazd jedną sekcją w ul. Gródeckiej w kierunku dworca kolejowego pobierano dodatkową opłatę, wynikającą z konieczności zaprzężenia do wagonu dodatkowego konia.

Źródło: Przewodnik po Lwowie wydany przy wspótudziale Wydziału Gospodarczego V. Zjazdu Lekarzy i Przyrodników Polskich, Lwów 1888, s. 16, 18; Przewodnik po Lwowie i Powszechnej Wystawie Krajowej wydany przez Towarzystwo dla Rozwoju i Upięhszania miasta, Lwów 1894, s. 2, 4; F. Barański, Przewodnik po Lwowie, Lwów 1902, s. 8-10; Przewodnik po Lwowie koleja elektryczna, Lwów 1913, s. 94, 116.

${ }^{124}$ CDIAUL, f. 146, op. 62, sp. 3277, Sprawozdanie magistratu miasta Lwowa w sprawie zmienionej taryfy jazdy na m. kolei elektrycznej, Lwów, 3 I 1901 r., k. 164-165.

${ }^{125}$ W 1902 r. dyrektor Tomicki wspólnie z inż. Zygmuntem Rodakowskim przystosowali eksperymentalnie palenisko jednego z kotłów parowych do opalania ropą naftowa. Próba okazała się na tyle pomyślna, że zdecydowano się wprowadzić opalanie ropne kotłów lwowskiej elektrowni; zob. Z. Rodakowski, Nafta jako opat dla przemystu, „Nafta. Organ Krajowego Towarzystwa Naftowego" 4, 1902, nr 4, s. 54; L. Rymar, Galicyjski przemyst naftowy, Kraków 1915, s. 78. 


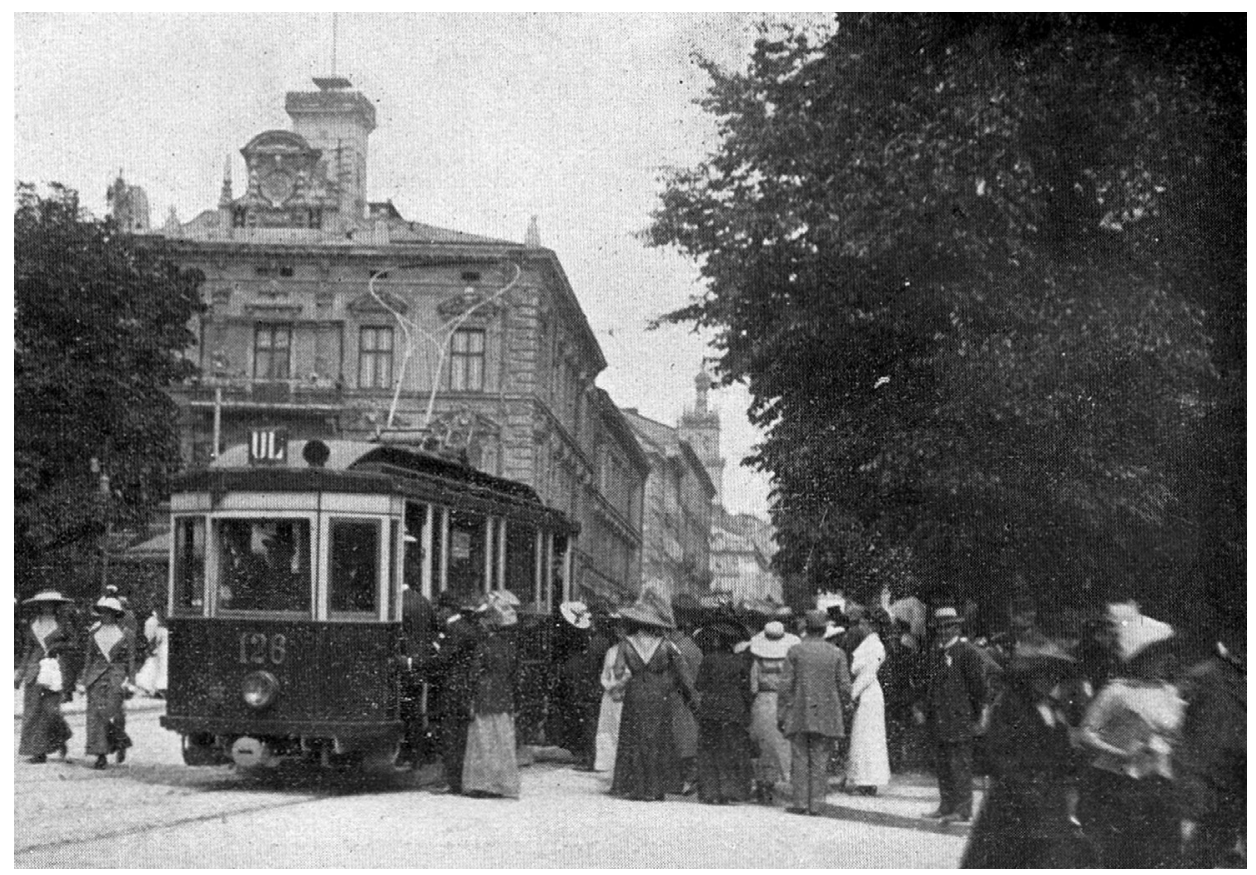

Il. 3. Wagon tramwajowy wykonany w zakładach Pierwszego Galicyjskiego Towarzystwa Akcyjnego Budowy Wagonów i Maszyn w Sanoku (przedtem K. Lipiński), skrzyżowanie ul. Hetmańskiej i Karola Ludwika, przed 1912 r.; źródło: J. Tomicki, Ze statystyki miejskich zakładów elektrycznych we Lwowie, Lwów 1912, s. 17.

Wbrew pesymistycznym prognozom sprzedaż biletów uprawniajaccych do przejazdu na uruchomionych w $1894 \mathrm{r}$. liniach stale wzrastała - z prawie 3,8 mln w 1894 r. do 11,8 mln w 1907 r. Liczba sprzedawanych w ciagu roku biletów tramwajowych na każdego mieszkańca w latach 1896-1903 wynosiła ok. 30. Od 1904 r. obserwujemy narastający wzrost sprzedaży biletów, który przekroczył liczbę 100 na każdego lwowianina w 1909 r. (zob. tab. 2). Już od końca 1903 r. w wagonach tramwajowych panował tłok do tego stopnia, że zagrażało to bezpieczeństwu jazdy (zob. il. 3) ${ }^{126}$. Brak możliwości rozbudowania sieci tramwajowej spowodował, że to „prawdziwe dobrodziejstwo dla mieszkańców Lwowa, stało się dzięki nieustannemu przepełnieniu wozów, utrapieniem

${ }^{126}$ DALO, f. 3, op. 1, sp. 4082 [Korespondencja z komisariatami policji; tekst obwieszczenia magistratu z 30 VI 1894 r.], k. 30-34; CDIAUL, f. 146, op. 68, sp. 3278, Sprawozdanie c.k. dyrektora policji lwowskiej w sprawie zarządzeń celem uchylenia przepełnienia wozów tramwaju elektrycznego, Lwów, 12 I 1904 r., k. 17-18; H. Feldstein, Sprawozdanie o budowie Miejskiego Zaktadu Elektrycznego i rozszerzeniu kolei elektrycznej we Lwowie w latach 1907, 1908 i 1909, Lwów 1911, s. 1. 
dla publiczności”'127. Po rozbudowaniu sieci tramwajowej miał miejsce jeszcze bardziej dynamiczny wzrost sprzedaży biletów, który w $1910 \mathrm{r}$. przekroczył liczbę $26 \mathrm{mln}$ (zob. tab. 2).

Tabela 2. Liczba sprzedanych biletów Miejskich Kolei Elektrycznych we Lwowie i przychody z ich sprzedaży w latach 1896-1914

\begin{tabular}{|c|c|c|c|c|}
\hline Lata & $\begin{array}{c}\text { Liczba } \\
\text { sprzedanych } \\
\text { biletów }\end{array}$ & $\begin{array}{c}\text { Liczba } \\
\text { sprzedanych } \\
\text { biletów } \\
\text { per capita }\end{array}$ & $\begin{array}{c}\text { Przychód ze } \\
\text { sprzedaży } \\
\text { biletów } \\
\text { abonamentowych } \\
\text { w koronach }\end{array}$ & $\begin{array}{c}\text { Przychód ze } \\
\text { sprzedaży } \\
\text { wszystkich } \\
\text { biletów } \\
\text { w koronach }\end{array}$ \\
\hline 1896 & 3785692 & 29 & 19192 & 405007 \\
\hline 1897 & 4165997 & 31 & 26016 & 447293 \\
\hline 1898 & 4347485 & 32 & 27809 & 465278 \\
\hline 1899 & 4555328 & 32,5 & 31025 & 485928 \\
\hline 1900 & 4726671 & 31,5 & 33874 & 507523 \\
\hline 1901 & 4262470 & 27 & 34793 & 523664 \\
\hline 1902 & 4297635 & 27,5 & 37860 & 538675 \\
\hline 1903 & 5020521 & 30,5 & 38194 & 570646 \\
\hline 1904 & 6780006 & 41,5 & 43942 & 654618 \\
\hline 1905 & 8149956 & 49,5 & 59554 & 754782 \\
\hline 1906 & 9886083 & 57 & 78874 & 893360 \\
\hline 1907 & 11806683 & 65,5 & 99171 & 1028497 \\
\hline 1908 & 13736648 & 76 & 118812 & 1157300 \\
\hline 1909 & 23185693 & 122 & 209151 & 2024117 \\
\hline 1910 & 26657555 & 133 & 269215 & 2390910 \\
\hline 1911 & 26601069 & 130 & 381357 & 3063641 \\
\hline 1912 & 31049929 & 141 & 489421 & 3337997 \\
\hline 1913 & 31185709 & 142 & 521009 & 3324574 \\
\hline 1914 & 22830093 & 103 & 365106 & 2582066 \\
\hline
\end{tabular}

Źródło: Sprawozdanie komisji budżetowej miasta Lwowa o projekcie budżetu gminy, tudzież funduszów i fundacji $w$ jej zarzadzie będacych za rok 1904, Lwów 1904, s. 39; „Wiadomości Statystyczne o Mieście Lwowie" (seria III), 10, 1905, s. 119-128; Sprawozdanie komisji budżetowej miasta Lwowa o projekcie budżetu gminy, tudziė̇ funduszów i fundacji w jej zarzqdzie będqcych za rok 1906, Lwów 1906, s. 18; Sprawozdanie prezydenta król. stot. miasta Lwowa z trzyletniej działalności reprezentacji miejskiej, magistratu $i$ zakładów miejskich w latach 1908, 1909, 1910, Lwów 1911, s. 15; J. Tomicki, Ze statystyki miejskich zaktadów elektrycznych we Lwowie, Lwów 1912, s. 3, 5-6; „Wiadomości Statystyczne o Mieście Lwowie” (seria III), 10, 1913, s. 169-170; „Wiadomości Statystyczne o Mieście Lwowie” (seria III), 14, 1914, s. 219-220; „Wiadomości Statystyczne o Mieście Lwowie” (seria III), 15, 1912-1922, s. 126.

Coraz bardziej popularne wśród lwowian przejazdy tramwajem, co było typowe dla innych miast europejskich, były przyczyną stagnacji usług dorożkarskich. Z końcem 1908 r. naliczono we Lwowie 4 fiakry,

${ }^{127}$ Miejska kolej elektryczna, „Kurier Lwowski”, 19 IV 1906, s. 3. 
271 dorożek na parę koni i 105 dorożek jednokonnych. Dziennikarz „Słowa Polskiego" zauważył, że po zwolnieniu koncesji na usługi dorożkarskie nikt się o nie nie ubiega, co wytłumaczył konkurencja tramwaju $^{128}$. Przejazd trzema sekcjami tramwajem elektrycznym w I klasie (trasa z dworca kolejowego do Śródmieścia) kosztował w 1902 r. 30 halerzy i był o 20 halerzy tańszy od przejazdu niewielką dorożka jednokonna (zob. tab. 1). Z tego powodu liczba użytkowanych we Lwowie dorożek tego typu zaczęła wyraźnie spadać. Żadnej konkurencji dla tramwaju nie stanowiły także trzy dorożki samobieżne (,automobilowe”), należące do Juliana Schrenzla, a kursujace po mieście od 1906 r. Przejazd nimi w obrębie jednej dzielnicy kosztował 2 korony ${ }^{129}$. Był to wprawdzie innowacyjny, jednak mało dostępny i raczej ekskluzywny środek transportu, konkurencyjny dla dużych dorożek dwukonnych.

Wdrożenie tramwaju elektrycznego, podobnie jak w wielkich miastach monarchii Habsburgów i Cesarstwa Niemiec, doprowadziło do konfliktu miasta ze spółką tramwaju konnego i następnie eliminacji tego środka transportu. W końcu ostatniej dekady XIX w. najczęściej to miejskie samorządy same decydowały się na rozszerzenie sieci tramwajów elektrycznych i budowę większych elektrowni ${ }^{130}$. Analogiczna sytuacja miała miejsce we Lwowie, gdzie miasto zdecydowało się przejąć elektrownię wraz z liniami tramwajowymi i samodzielnie dostarczać energię elektryczną do oświetlania teatru oraz nielicznych prywatnych odbiorców $^{131}$. Oczekiwanie rozbudowania linii tramwajowych wśród lwowian na początku XX w. było na tyle duże, że 38 majętnych mieszkańców dzielnicy halickiej w rejonie Nowego Światu i Bajek zaoferowało władzom miasta w maju 1905 r. poręczenie pożyczki w kwocie 87 tys. koron na wybudowanie jednotorowej linii tramwajowej od ul. Krzyżowej do fabryki gipsu Franza $^{132}$. Rozbudowa linii tramwajowych przeprowadzona w latach

${ }_{128}$ Dorożki we Lwowie, „Słowo Polskie”, 26 XI 1908, s. 7. O konkurencji tramwajów względem dorożek por. J.P. McKay, dz. cyt., s. 193-195.

${ }^{129}$ Dorożki automobilowe, „Kurier Lwowski”, 16 VIII 1906, s. 2.

${ }^{130}$ W.R. Krabbe, Kommunalpolitik und Industrialisierung. Die Entfaltung der städtischen Leistungsverwaltung im 19. und frühen 20. Jahrhundert. Fallstudien zu Dortmund und Münster, Stuttgart 1985 (Schriften Deutschen Instituts für Urbanistik, 74), s. 70-77; H.P. Hye, Die Wende zur Industrie- und Wissensgesellschaft, w: Soziale Strukturen. Von der feudal-agrarischen zur bürgerlich-industriellen Gesellschaft, cz. 1/1: Lebens- und Arbeitswelten in der industriellen Revolution, red. U. Harmat, Wien 2010 (Die Habsburgermonarchie 1848-1918, 9), s. 51-54.

131 H. Feldstein, dz. cyt., s. 1-2.

132 AGAD, zesp. 310, sygn. 362a, Magistrat miasta Lwowa do c.k. Ministerstwa Kolei Żelaznych, Lwów, 31 VIII 1906 r., s. 220-221; Komisja elektryczna. Posiedzenie dnia 11 lipca, „Dziennik Lwowski. Organ urzędowy gminny król. stoł. miasta Lwowa” 1, 
1907-1910 spowodowała o wiele większe zapotrzebowanie na energię elektryczna, którą zapewniła znacznie większa elektrownia, wzniesiona na terenie miejskiego folwarku - Persenkówki. Koszty wykonania linii tramwajowych wraz z nową elektrownią i siecią elektryczną wyniosły prawie $15,5 \mathrm{mln}$ koron. Dla należytego ukazania wysiłku inwestycyjnego miasta przypomnę, że budowa linii tramwajowych i elektrowni w 1894 r., w tym jej rozbudowa w 1900 r., kosztowała ponad 2,3 mln koron. Potrzebny kapitał pozyskano przez emisję obligacji kolejowych w Banku Krajowym Królestwa Galicji i Lodomerii ${ }^{133}$.

Po uruchomieniu na przełomie 1908 i 1909 r. elektrowni na Persenkówce okazało się, że wykonane trzy agregaty parowo-elektryczne moga nie sprostać zapotrzebowaniu na energię elektryczna. Jak zauważył dyrektor Miejskich Zakładów Elektrycznych, „podczas gdy w dziewięciu latach od 1900 do 1909 r. cała ilość załączonych lamp [elektrycznych T.D.] wynosiła 45,8 tys. sztuk, to w przeciagu 12 miesięcy, obecnie załączono ich 59 tys. [...]. Podczas gdy przez dziewięć lat osiagnęliśmy 1203 instalacji domowych, to obecnie liczymy ich 3587”134. Największy wzrost liczby instalacji elektrycznych zakładanych w prywatnych budynkach nastapił od końca 1908 r. Wówczas większość właścicieli nowych kamienic budowanych w mieście decydowała się na ich podłączenie do sieci elektrycznej. W głównych ulicach miastach ustawiono kunsztowne latarnie z łukowymi lampami elektrycznymi. Miały one oświetlać reprezentacyjne ulice i być uzupełnieniem rozproszonego oświetlenia gazowego ${ }^{135}$, które zaczęto uważać wówczas za anachronizm, podobnie zreszta jak tramwaj konny ${ }^{136}$. Elektryczność na obszarze Galicji najbardziej upowszechniła się we Lwowie, stając się symbolem nowoczesności. Stąd coraz częściej takim mianem zaczęto określać galicyjską stolicę tuż przed wybuchem I wojny światowej ${ }^{137}$.

1906, nr 1, s. 28; Rada miejska. 55. posiedzenie dnia 6 września, „Dziennik Lwowski. Organ urzędowy gminny król. stoł. miasta Lwowa” 1, 1906, nr 6, s. 100.

${ }^{133}$ H. Feldstein, dz. cyt., s. 2-3; J. Tomicki, dz. cyt., s. 2; S. Hoszowski, dz. cyt., s. 97.

${ }^{134}$ Naukowa Biblioteka Lwowskiego Narodowego Uniwersytetu im. I. Franki, sygn. 89758 III, cz. 1, Wnioski dyrekcji Miejskich Zakładów Elektrycznych, oprac. J. Tomicki [Lwów 1909], k. I.

${ }_{135}$ Corso we Lwowie, „Gazeta Narodowa”, 29 III 1908, s. 2.

${ }^{136}$ W. Schivelbusch, Disenchanted Night. The Industrialisation of Light in the Nineteenth Century, tłum. z niem. A. Davis, Berkeley-Los Angeles 1988, s. 64-73; T. Dywan, Przemyst gazowniczy we Lwowie..., s. 117-119.

137 E. Paczoska, Stolica nowoczesności? W poszukiwaniu „tekstu lwowskiego”, w: Modernistyczny Lwów. Teksty życia, teksty sztuki, red, E. Paczoska, D.M. Osiński, Warszawa 2009, s. 11-26; J. Purchla, Kraków i Lwów wobec nowoczesności, w: Kraków $i$ Galicja wobec przemian cywilizacyjnych (1866-1914). Studia i szkice, red. K. Fiołek, M. Stala, Kraków 2011, s. 223-238. 


\section{Bibliografia}

Altenberg M., Kozłowski S., Działalność elektryfikacyjna m. Lwowa, Warszawa 1937 (nadb. z: „Przegląd Elektrotechniczny” 19, 1937, nr 5).

Feldstein H., Sprawozdanie o budowie Miejskiego Zakładu Elektrycznego i rozszerzeniu kolei elektrycznej we Lwowie w latach 1907, 1908 i 1909, Lwów 1911. Latos T., Tramwaj konny w Krakowie (1882-1901), w: Społeczeństwo, kultura, inteligencja. Studia historyczne ofiarowane Profesor Irenie Homoli-Skapskiej, red. E. Orman, G. Nieć, Kraków-Warszawa 2009 (Regiony, Historia, Kultura, 6), s. 267-280.

McKay J.P., Tramways and Trolleys. The Rise of Urban Mass Transport in Europe, Princeton 1976.

Miasto Lwów w okresie samorzadu 1870-1895, Lwów 1896.

Rechłowicz M., Szajner J., Poczatki tramwajów lwowskich (1880-1896), w: Archeologia przemysłowa $w$ Polsce, t. 4, red. S. Januszewski, Wrocław 2013, s. 85-114.

Schmucki B., The Machine in the City. Public Appropriation of the Tramway in Britain and Germany 1870-1915, „Journal of Urban History” 38, 2012, nr 6, s. 1060-1093.

Sielicki T., Wrocławskie tramwaje konne, Wrocław 2017.

Sroka Ł.T., Rada Miejska we Lwowie w okresie autonomii galicyjskiej 1870 -1914. Studium o elicie władzy, Kraków 2012 (Uniwersytet Pedagogiczny im. Komisji Edukacji Narodowej w Krakowie. Prace Monograficzne, 621).

Szajner J., Rechłowicz M., Tramwaje lwowskie 1880-1944, Łódź 2020.

Tomicki J., Ze statystyki miejskich zakładów elektrycznych we Lwowie, Lwów 1912. Wesołowski J., Transport miejski. Ewolucja i problemy wspótczesne, Łódź 2002 (Zeszyty Naukowe Politechniki Łódzkiej, 918; Rozprawy Naukowe, 319).

Кріжанівський А., Історія електрифбкаціӥ Львівщини, Львів 2015.

Tomasz Dywan

Public transport in Lviv in the years 1879-1914. On the issue of developing modern urban infrastructure in Galicia

(Summary)

The text seeks to present the circumstances of development and later use of modern infrastructure solutions for mass public transportation in Lviv. As opposed to other European towns, the first means of public transport introduced in Lviv was not the omnibus but the horse-drawn tram. In the years 1879-1880 , a tram network was opened by the Trieste Tramway Society (Società Triestina Tranway). In exchange for the effort put in the project, the society was granted a fifty-year license to operate the horsecar. As in many other Central 
European cities, a conflict soon broke out between the local self-government and the investor, as the latter was reluctant to take the risk of further expanding the existing network. The crisis was overcome thanks to Lviv hosting the Polish General Exhibition in 1894. In preparations for the event, an omnibus service started to operate in the city, but the antiquated means of transport soon proved to be insufficient to meet the demand for cheap transport. The municipal authorities therefore decided to invest in an innovative tramway powered by electricity. Wishing to avoid investing public funds into such a risky undertaking, the city commissioned the project to the company Siemens \& Halske. Despite many expecting the initiative to fail, the electric tramway soon started to bring profit and became serious competition for the horsecar. Fearing mass loss of clients, the Trieste Tramway Society successfully blocked further development of the electric tram network, refusing to allow its routes to intersect with those operated by horse-drawn tramway. The city purchased the electric tramway from Siemens \& Halske in 1896, but it only managed to significantly expand its network in 1907, having also purchased the horsecar service. The electric tram then became the principal means of public transport in Lviv, and its vast popularity among the town dwellers resulted in decreased use of horse-drawn carts. The number of tram rides per resident was similar to the figures in other Central European cities. On the eve of World War I, electricity was becoming an ever more popular power source for lighting and running engines. Trams and electricity led to Galicia's capital being perceived as a truly "modern city."

Tomasz Dywan - adiunkt w Instytucie Historycznym Uniwersytetu Wrocławskiego. Doktor nauk historycznych, autor pracy Ksztattowanie kultury prowincjonalnej $w$ sanktuariach maryjnych na kresach południowo-wschodnich dawnej Rzeczypospolitej (Łódź 2014). Swoje zainteresowania badawcze koncentruje na religijności i kulturze dawnej Rzeczypospolitej, a także historii nauki i techniki, ze szczególnym uwzględnieniem Europy Środkowej od końca XVI do początku XX w.

Tomasz Dywan - assistant professor in the Institute of History at the University of Wrocław. Doctoral degree in humanities, author of the work Kształtowanie kultury prowincjonalnej $w$ sanktuariach maryjnych na kresach południowo-wschodnich dawnej Rzeczypospolitej (2014). His research interests focus on the religiosity and culture of Old Poland as well as history of science and technology, particularly in Central Europe from the late sixteenth century until the early twentieth century.

E-mail: tomasz.dywan@uwr.edu.pl; dywantl@gmail.com 